\title{
What Do Smoothed Earnings Tell Us about the Future?*
}

\author{
Yusuke TAKAsu ${ }^{\dagger}$ \\ Graduate School of Commerce and Management \\ HITOTSUBASHI UNIVERSITY
}

\author{
Makoto Nakano \\ Graduate School of Commerce and Management \\ HITOTSUBASHI UNIVERSITY
}

\begin{abstract}
This study analyzes the information contents of income smoothing behavior, especially the role of income smoothing behavior as a signal of future performance. What do smoothed earnings tell us about the future? To answer this research question, this paper focuses on earnings persistence and dividend policy based on two prior survey papers. These two issues (earnings persistence and dividend policy) are the foci of this study, based on Japanese managers' responses to questions regarding their motivation for income smoothing. This paper provides two new pieces of evidence. First, income smoothing in the previous period relates positively to future earnings persistence. Second, firms that engage in more smoothing tend to pay more stable dividends in the future, even when we control for past dividend policy, fundamental factors, and corporate governance factors. These results indicate that income smoothing behavior is likely to reflect future stability of earnings performance. Income smoothing acts as a vehicle through which managers can reveal private information about future earnings persistence and future dividend policy. The empirical evidence supports the information view rather than a garbling view of income smoothing, and sheds light on the bright side of smoothed earnings rather than its dark side.
\end{abstract}

JEL Classification: M41; G14; G35

Key Words: Income Smoothing; Private Information; Earnings Persistence; Dividened Policy

\footnotetext{
* We wish to warmly thank the editor in chief (Hidetoshi Yamaji), two anonymous referees for many engaging comments and some challenging requests. We have also benefited from discussions with participants at the European Accounting Association 35th Annual Congress in Ljubljana, Slovenia, 23rd Asian-Pacific Conference on International Accounting Issues in Beijing, China, and TJAR Doctoral Workshop. The authors thank financial support from the GCOE program "Innovation in the Japanese Corporation" at Hitotsubashi University. Final thanks go to our colleagues. All remaining errors are our own.

† Corresponding Author. Address Hitotsubashi University 2-1, Naka, Kunitachi-shi, Tokyo, JAPAN.

Telephone+81(42) 580-8745 E-mail cd121006@g.hit-u.ac.jp
} 


\section{Introduction}

Earnings quality is one of the most controversial issues, and a subject of growing concern in financial accounting research and accounting-standards settings (Francis et al. 2004; Barth et al. 2008; Dechow et al. 2010). It has been examined from a number of perspectives. There exist several concepts and measures of earnings quality; Francis et al. (2004), for example, present seven earnings attributes: accrual quality, persistence, predictability, smoothness, value relevance, timeliness, and conservatism. Among these earnings attributes, this study sheds light on income smoothing. The existence of income smoothing itself has long been discussed in practice and in academic literature, and some empirical and analytical studies focus on income smoothing. In particular, many researchers have analyzed the relationship between income smoothing behavior and either stock returns or cost of equity capital, e.g. (Hunt et al. 2000; Francis et al. 2004; Tucker and Zarowin 2006; McInnis 2010). These studies assume that income smoothing behavior reflects a manager's private information regarding future performance (Francis et al. 2004). There is, however, a counterargument that income smoothing behavior obfuscates earnings information (Bhattacharya et al. 2003; Leuz et al. 2003). This study analyzes the information contents of income smoothing behavior, especially the role of income smoothing behavior as a signal of future performance. What do smoothed earnings tell us about the future? To answer this research question, this paper focuses on earnings persistence and dividend policy, based on two survey papers by Graham et al. (2005) and Suda and Hanaeda (2008).

Top management has shown a clear preference for income smoothing. Graham et al. (2005, p. 44) reported that "an overwhelming $96.9 \%$ of the survey respondents indicate that they prefer a smooth earnings path," as it keeps cash flow constant. Why do top managers prefer income smoothing? In a comparable survey undertaken in Japan, the two reasons most frequently cited were (1) it enables stable dividends, and (2) it assures customers/suppliers that a business is stable (Suda and Hanaeda 2008). Therefore, it seems that "stability" is a key word in understanding the motivation for income smoothing. If income smoothing behavior reflects a manager's private information about future performance, the earnings of firms that engage in more smoothing are more informative. On the other hand, if income smoothing reflects garbling (opportunistic) behavior, the earnings of firms that engage in more smoothing would not inform outsiders about any valuable information.

This study focuses on Japanese firms for two reasons. First, John et al. (2008) and Acharya et al. (2011) reported that the time-series volatility of return on assets in Japan is the lowest among 35 countries around the world. For example, although the average volatility of American, British, German, and Australian firms is 8.8 percent, 7.1 percent, 5.7 percent, and 12.1 percent, respectively, the average volatility of Japanese firms is only 2.2 percent. This evidence suggests there is a high possibility that Japanese firms' managers aggressively smooth earnings compared with managers in other countries. It is beneficial for us to test our hypotheses in the Japanese setting because we can explore the unique earnings management behaviors that may be specific to Japanese firms.

Second, Denis and Osobov (2008) found that more Japanese firms pay dividends compared with firms in other countries. For example, although the proportion of dividend-paying firms in the United States and Canada in 2002 was 19.0 percent and 19.9 percent, respectively, the proportion of dividend-paying firms in Japan in 2002 is 83.8 percent. This fact may produce pressure on managers to pay dividends. Because most Japanese firms pay dividends, we can use a large sample to test our hypothesis. Moreover, during the sample period, approximately 40 percent of Japanese firms adopted a stable dividend policy. This may produce pressure on managers to maintain stable dividends, thereby encouraging managers to smooth earnings in order to maintain stable dividends. This pressure 
might urge managers to engage in ad hoc income smoothing without ample consideration of future performance.

This study provides two new empirical findings. First, income smoothing relates positively to earnings persistence. This implies that income smoothing behavior reflects high earnings persistence in the future. Second, firms those engage in more smoothing pay stable dividends in the future. There are fewer non-dividend payers among firms that engage in more smoothing than among firms that engage in less smoothing. Income smoothing is informative with respect to a firm's future stable dividends, and functions as a signal even when we control for past dividend policy, fundamental factors, and corporate governance factors. Given Lintner (1956)'s argument that the change in dividend amount reflects the change in the level of long-term and persistent earnings, it would appear that income smoothing behavior reflects long-term stability of firm performance.

Overall, the evidence shows that Japanese managers, on average, tend to smooth earnings with future earnings performance in mind. The results are robust to the alternative definitions of income smoothing posited by Hunt et al. (2000), Leuz et al. (2003), Francis et al. (2004), and Tucker and Zarowin (2006), and to varying model specifications.

This study makes several contributions to the literature and understanding of income smoothing behavior. First, we build on recent advances in the literature vis-à-vis earnings quality, especially income smoothing. Although most prior studies focus on the economic consequences of income smoothing-for example, Francis et al. (2004) found that firms that engage in more smoothing have lower cost of capital than firms that engage in less smoothing-few studies provide evidence as to whether or not income smoothing reflects future performance. The current study fills this gap.

Second, the empirical evidence supports the information view rather than a garbling view of income smoothing. As mentioned above, few studies provide evidence as to whether income smoothing reflects future performance. The exception is Tucker and Zarowin (2006), who provided evidence that income smoothing reflects future earnings persistence, although earnings persistence may not fully stand as a proxy for future stability. Managers' discretion may be included in both current and future net income. Furthermore, the earnings persistence coefficient estimated from the first-order auto-regressive calculation process might capture only the short-term stability of a firm's performance. The current study analyzes the information content of income smoothing from two perspectives; short-term stability (earnings persistence) and long-term stability (dividend policy). From these analyses, this study sheds light on the bright side of smoothed earnings rather than its dark side.

The remainder of this paper is organized as follows. Section 2 reviews the literature and presents the hypotheses. Section 3 provides details about the research design and sampling methodology. Section 4 examines the relationship between income smoothing and future earnings persistence and the relation between income smoothing and future dividend policy, to investigate the role of smoothed earnings paths as a signal about a firm's future performance stability. Section 5 includes robustness checks. Section 6 summarizes the paper and provides concluding remarks.

\section{Prior Literature and Hypotheses}

With respect to managers' motivations vis-à-vis financial reporting, some influential survey articles have come from the United States (Graham et al. 2005) and Japan (Suda and Hanaeda 2008). In the United States, "an overwhelming $96.9 \%$ of the survey respondents indicate that they prefer a 
smooth earnings path" (Graham et al. 2005, p. 44), as it keeps cash flow constant. In Japan, 44 percent of the respondents in Suda and Hanaeda (2008)'s survey indicated that they might sacrifice corporate value in order to report smoothed income. Managers have a high tendency to avoid a bumpy earnings path, in both the United States and Japan.

Why do Japanese managers smooth earnings? What are their motivations for doing so? According to Suda and Hanaeda (2008), ${ }^{1}$ the top two answers are that doing so (1) enables stable dividends (62.5 percent) and (2) assures customers/suppliers that the business is stable (55.2 percent). This study investigates the link between income smoothing and the stability of Japanese firms, in terms of these two managerial responses. ${ }^{2}$

Although managers have strong preference for income smoothing, there are two conflicting viewpoints on income smoothing: (1) the information view and (2) the garbling view. First, the information view posits that managers can communicate private information about future earnings through smoothing behavior, as well as mitigate any information asymmetry problems (Francis et al. 2004). Tucker and Zarowin (2006) found that the future earnings of firms that engage in more smoothing are more likely to be impounded into their current stock returns than those of firms that engage in less smoothing; they concluded that income smoothing improves the informativeness of earnings.

Second, in contrast, smoothed income may include garbling information. Managers may manipulate reported earnings for private reasons, including those related to their own compensation (Healy 1985) and career-related concerns in the manager labor market. Leuz et al. (2003) viewed income smoothing as a device used by insiders to obfuscate their consumption of private-control benefits, and Bhattacharya et al. (2003), in their international comparison study, contended that smoothing leads to greater earnings "opacity." Which perspective is correct? This is still an open question, and it seems to be an empirical issue.

While it is possible to categorize viewpoints conceptually as being in one of the two aforementioned conflicting streams, it can be difficult to disentangle the actual smoothness of reported earnings. Reported earnings may reflect the smoothness of (1) the fundamental earnings process, (2) financial accounting rules, or (3) managers' intentional earnings manipulation (Dechow et al. 2010).

The current paper defines income smoothing as a manager's tendency to exhibit accounting behavior that decreases reported income volatility, compared to that of pre-discretionary income. Cohen et al. (2008) found that firms have changed from accrued to real earnings management following the implementation of the Sarbanes-Oxley Act (SOX); the reason is that SOX has made accrual-based earnings management more costly. Considering their finding, the current paper's definition of smoothing considers both accrual discretion and real discretion.

Using this definition, and given above managers' preference for income smoothing, their motivation to smooth earnings, and the two conflicting perspectives, we investigate whether income smoothing behavior is informative or opportunistic. If income smoothing behavior reflects managers' private information regarding future performance, which is consistent with Francis et al. (2004)'s argument, then the earnings of firms that engage in more smoothing are more informative. In

\footnotetext{
${ }^{1}$ When asked why they smooth income, the top three answers among managers in the United States were that doing so (1) leads to perceptions among investors that the firm is not risky, (2) makes it easier for analysts/investors to predict future earnings, and (3) assures customers/suppliers that the business is stable (Graham et al. 2005).

2 Shuto and Iwasaki (2012) found that a stable shareholder structure encourages managers to perform income smoothing in Japan. They focused on the determinants of income smoothing. Our study, in contrast, investigates both the economic consequences and signaling role of income smoothing.
} 
particular, if income smoothing behavior truly reflects future firm stability, which is what managers want to convey to outsiders by smoothing earnings (Suda and Hanaeda 2008), then outsiders can recognize the stability by observing the smoothed earnings path. On the other hand, if income smoothing reflects garbling (opportunistic) behavior, that is, managers' behavior to deceive outsiders and obfuscate their consumption of private-control benefits (Leuz et al. 2003), then the earnings of firms that engage in more smoothing would not offer outsiders any valuable information.

To investigate this effect of income smoothing behavior, we test two hypotheses. In the first hypothesis, we directly test the relationship between current smoothed earnings and future performance. This study focuses on earnings persistence. Dichev and Tang (2009) found that earnings volatility relates negatively to earnings persistence. This implies that low earnings volatility in the past has the role of a signal regarding future persistent earnings to outsiders. Extending Dichev and Tang (2009)'s research, Nakano and Takasu (2011) provided evidence that earnings management in the previous period has a negative impact on future earnings persistence. This implies that past earnings management has the role of a negative signal to outsiders regarding future earnings persistence. Although these studies analyzed the relationship between earnings volatility and earnings persistence, they did not address income smoothing behavior. ${ }^{3}$ As mentioned above, earnings smoothness (i.e., low earnings volatility) may reflect both a firm's fundamentals and manager discretion (Dechow et al. 2010). However, Dichev and Tang (2009) made little consideration for this point in their research design. If income smoothing behavior is ad hoc behavior in order to smooth current earnings without consideration on future performance, discretionary smoothed earnings might not have a role as a signal regarding future earnings persistence. On the other hand, as long as income smoothing behavior reflects managers' private information about future earnings stability, discretionary smoothed earnings could have a role as a signal about future earnings persistence.

From the above discussions, we develop the first hypothesis:

H1: Firms that engaged in more smoothing in the past (period $t-4$ to $t$ ) have higher earnings persistence (period $t$ to $t+1$ ) than firms that engaged in less smoothing.

A similar analysis was conducted by Tucker and Zarowin (2006), who analyzed the relationship between income smoothing and earnings persistence. Earnings persistence, however, may not be fully appropriate to estimate future performance stability because future net income includes management discretion. To cope with this problem, we also analyze "adjusted" earnings persistence, which is the coefficient of the regression of pre-discretionary income for year $t+1$ on net income for year $t$. If income smoothing behavior reflects managers' private information about future earnings stability and approximates permanent earnings thorough current smoothed earnings, the coefficient would also become higher even when pre-discretionary income for year $t+1$ is used as the dependent variable.

In the second hypothesis, we analyze the relationship between current smoothed earnings and future dividend policy. Although this test indirectly analyzes the relationship between current smoothed earnings and future earnings, we consider future dividend policy as worthwhile in investigating whether income smoothing behavior is informative or opportunistic because it was suggested by Lintner (1956) that the change in dividend amount is dependent on the change in the level of long-term and persistent earnings. Therefore, from this argument, it is implied that the

3 Although Nakano and Takasu (2011) analyzed earnings management in general situations, they did not focus on the income smoothing situation specifically. 
change in dividend policy might reflect management belief about future earnings performance.

Denis and Osobov (2008) reported that over 80 percent of Japanese firms paid dividends during the period 1990 - 2002. When compared with other countries, this is a unique dividend policy. For instance, the percentage of dividend payers in 2002 was 19.0 percent in the United States and 19.9 percent in Canada. In contrast, 83.8 percent of Japanese firms paid dividends in 2002. In addition, our calculation documents that 40 percent of firms, on average, are categorized as "stable payers" over the period 19952009. "Stable payers" are firms paying the same amount of dividend per share for two consecutive years. It should be noted that stable dividends are a uniquely Japanese payout strategy.

Through a survey of Japanese firms, Suda and Hanaeda (2008) found that 62.5 percent of respondents expected income smoothing to enable stable dividends, and recognized this point as the most important motivation behind their smoothing behavior. Since this income smoothing motivation seems to reflect managers' recognition of the importance of stable dividends, it seems managers tend to smooth current earnings in order to pay stable dividends in the current year. ${ }^{4}$ If income smoothing behavior reflects earnings garbling behavior to pay stable dividends in the current year without consideration of future performance, firms that engage in more smoothing will tend to pay volatile dividends in the future because managers may not be able to maintain ad hoc income smoothing behavior in the future. On the other hand, if income smoothing behavior reflects future firm performance stability, firms that engaged in more smoothing will tend to pay stable dividends in the future. If current income smoothing behavior positively relates to a stable dividend policy in the future, current income smoothing has a role as a positive signal about the firm's future performance stability because, following Linter (1956)'s implication, a stable dividend policy reflects managers' belief about future performance stability,

From the above discussions, we develop the second hypothesis:

H2: Firms that engaged in more smoothing in the past (period $t-4$ to $t$ ) have a higher tendency to pay stable dividends in the future (periods $t$ to $t+1$ and $t+1$ to $t+2$ ) than firms that engaged in less smoothing.

Hypothesis 2 assumes that income smoothing behavior functions as a signal of future dividend stability.

Testing these two hypotheses (earnings persistence and stable dividend policy), we investigate the relationship between income smoothing behavior and future firm stability. In this study, we capture the firm's stability through future earnings persistence and future stable dividends. On one hand, we regard future earnings persistence as short-term stability of firm performance because future earnings persistence is measured by the coefficient estimated from the regression of net income for year $t+1$ on the net income for year t. On the other hand, we regard future stable dividend policy as longer-term stability of firm performance because Lintner (1956) suggested that the change in dividend amount is dependent on the change in the level of long-term and persistent earnings. Although short-term earnings persistence is viewed as one of the factors that affect dividend policy, it would appear that stable dividend policy reflects not only short-term earnings persistence but also long-term stability of earnings performance.

\footnotetext{
4 Note that there is little consensus regarding the reason why managers prefer stable dividends in Japan, despite their strong preference for stable dividends. This is one of the limitations of our research. Serita et al. (2011), however, provided a clue to interpreting this phenomenon. They showed that some institutional investors, specifically banks and pension funds, prefer stable dividends. If managers want to cater to the demands of these institutional investors, they might choose stable dividend policies. In particular, because Japanese firms are highly connected with a specific bank (i.e., main bank), managers might cater to the demands of that bank.
} 


\section{Research Design}

\subsection{Income Smoothing Measure}

The current study defines "income smoothing" as a manager's will to decrease reported income volatility compared to that of pre-discretionary income. The proxy variable of the degree of smoothing is defined as firm-specific historical volatility of net income that is calculated as standard deviation of it over the most recent five years, divided by volatility of pre-discretionary income that is calculated as standard deviation of it over the most recent five years $(\operatorname{Vol}(N I) / \operatorname{Vol}(P D I))$. Both net income $(N I)$ and pre-discretionary income $(P D I)$ are deflated by total assets at the beginning of year. The smaller this variable is, the more likely managers are to smooth income. Leuz et al. (2003) and Francis et al. (2004) use basically the same variable: volatility of reported income, divided by volatility of cash flow from operations. Hunt et al. (2000)'s smoothness variable is similar to that of the current study, except the former includes only accounting discretion; the proxy variable of the current study, on the other hand, includes both accounting discretion and a part of real discretion. The current study's measure of manager's smoothing behavior is the most accurate, because the denominator is measuring the purely pre-discretionary income portion, before either accrual discretion or real discretion has been exercised.

When measuring PDI, the discretionary portion must be specified. As mentioned, discretion includes both accounting discretion and real discretion. First, this study explains the procedure used to estimate discretionary accruals $(D A C)$; it follows the standard methodology. Total accruals $(T A C)$ are defined as follows:

Total accrual $=(\Delta$ current assets $-\Delta$ cash and cash equivalents $)$

- $\left(\Delta\right.$ current liabilities $-\Delta$ financing item $\left.{ }^{5}\right)-\Delta$ other allowance ${ }^{6}-$ depreciation $^{2}$

$D A C$ is estimated as $T A C$ minus nondiscretionary accruals $(N D A C) . N D A C$ is estimated via a regression-based approach, following Kothari et al. (2005). ${ }^{7}$ In particular, this study estimates $N D A C$ by industry-year from regression Model (1).

$$
\begin{aligned}
T A C_{t}= & \delta_{0}+\delta_{1}\left(1 / A_{t-1}\right)+\delta_{2}\left(\triangle S_{t}-\triangle R E C_{t}\right)+\delta_{3} P P E_{t}+\delta_{4} R O A_{t}+\varepsilon_{t} \\
T A C_{t}= & \text { total accruals in Fiscal Year } \mathrm{t}, \text { deflated by total assets } \\
& \text { at the beginning of Fiscal Year } \mathrm{t} \\
A_{t-1}= & \text { total assets at the end of Fiscal Year } \mathrm{t}-1 \\
\Delta S_{t}= & \text { the change in sales from Fiscal Year } \mathrm{t}-1 \text { to } \mathrm{t}, \text { deflated by total assets } \\
& \text { at the beginning of Fiscal Year } \mathrm{t}
\end{aligned}
$$

\footnotetext{
${ }^{5} \Delta$ financing item is the sum of the following items: change in short-term debt, change in commercial paper, change in current portion of bonds and convertible bonds.

${ }^{6} \Delta$ other allowance is the sum of the following items: change in allowance for doubtful accounts classified as fixed assets and change in long-term provision.

7 This study uses discretionary accruals estimated from Kothari et al. (2005) model. This study focuses on income smoothing wherein proxies are calculated by considering the variability of earnings. Because Kothari et al. (2005) model uses $R O A$ as an explanatory variable, the effect of earnings on discretionary accruals is, already and at least partially, removed from our main analyses. The results, however, remain unchanged even when we use alternative models, in particular Jones (1991) model and Dechow et al. (1995) model to calculate discretionary accruals.
} 




(net income before extraordinary items $=$ net income \pm loss and gain from minority interests gain form extraordinary items + loss from extraordinary items)

$D A C$ is defined as the residual of Model (1).

Second, this study adopts the gain/loss on the sale of marketable securities reported in extraordinary items, as a real discretion $(R D)$ proxy. This paper does not include other real discretion items such as research and development (R\&D), advertising, or labor expenses because these items are included in calculation of operating income and we cannot distinguish the effect of these discretionary expenses on the calculation of $D A C$ from the overall effect of the discretionary expenses on earnings. Also, similar variable is used in Herrmann et al. (2003). They regard excess income from the sale of assets which is measured as income from the sale of fixed assets and marketable securities minus the median for the corresponding industry and year. They find that firms tend to increase (decrease) earnings through the sale of fixed assets and marketable securities when current reported income is below (above) managers' forecasts. Due to data restrictions, however, we could not include other items such as gains/losses from the sale of fixed assets. Furthermore, in our sample, over fifty percent of firm-years report that the gain/ loss on the sale of marketable securities in extraordinary items is zero. This might imply that there is a low possibility that a firm's sale of marketable securities is affected by the trend of the same industry-year firms. If certain firm's sale of marketable securities was affected by the trend, there are more firm-years that report the gain/loss on the sale of marketable securities in extraordinary items. Therefore, we regard the gain/loss on the sale of marketable securities reported in extraordinary items as $R D .^{8}$ In order to take account of the effect of tax, we estimate the gain/loss on the sale of marketable securities after tax. In this paper, after tax $R D(A T R D)$ is calculated by multiplying $R D$ by $0.6 .^{9} A T R D$ is also deflated by total assets at the beginning of Fiscal Year. ${ }^{10}$

The sum of $D A C$ and $A T R D$ is defined as total earnings management portion (TEM). PDI is defined as NI minus TEM.

Total Earnings Management $(T E M)=D A C+A T R D$
Pre-discretionary income $(P D I)$
$=$ Net income $(N I)$ - Total earnings management $(T E M)$

\footnotetext{
8 Tests are also performed using the gain/loss on the sale of marketable securities minus the median for the corresponding industry and year as $R D$. The results remain similar to those reported.

9 To compute the after tax amounts, generally, 40 percent is used as effective tax rate in Japan.

${ }^{10}$ In prior literature, normal asset sales are estimated to calculate abnormal asset sales (e.g. Gunny 2010). If a large part of $R D$ is normal asset sales, our results might be misleading. We regard, however, this concern as a trivial one, because in the robustness checks where we assume only $D A C$ to be the discretionary portion of $N I$, the results remain unchanged.
} 
Finally, this study's proxy variable of smoothness is calculated as the volatility of $N I$ divided by the volatility of $P D I$ (i.e., $\operatorname{Vol}(N I) / \operatorname{Vol}(P D I))$. To control for industry and time effects, following Tucker and Zarowin (2006), this study uses a firm's reversed fractional ranking of income smoothing (between 0 and 1) within its industry-year ${ }^{11}$ and refers to it as Income Smoothing $(I S) .{ }^{12}$ Higher- $I S$ firms aggressively smooth income in the industry-years to which they belong. Hereafter, this paper uses $I S$ as a measure of degree of income smoothing. In Section 5, we conduct several robustness checks with three additional IS measures; IS2, IS3, IS4.

\subsection{Framework of Analysis}

This paper investigates whether smoothed earnings reflect firm's future stability of performance through the analyses about earnings persistence and dividend policy. This subsection explains the framework and models of this study's analysis.

\subsubsection{Earnings Persistence}

In order to investigate the link between smoothing and earnings persistence, this study relies on commonly used autoregressive regressions of one-year-ahead earnings on current earnings.

$$
N I_{t+1}=\alpha+\beta N I_{t}+\varepsilon_{t+1}
$$

Based on cross-sectional regression, earnings persistence $(\beta)$ is estimated. When $\beta$ is close to 1 , earning persistence is high. In contrast, when $\beta$ is close to 0 , earnings include a more transitory factor and persistence is low.

In the first analysis, $I S_{\mathrm{t}}$ quintiles are formed based on the the value of $I S_{\mathrm{t}}$ and persistence is compared. The methodology of Dichev and Tang (2009) is followed for testing differences in persistence coefficients across quintiles. More specifically, Quintiles 1 (the least smoothing quintile) and 5 (the most smoothing quintile) observations are combined, and Regression (3) on these combined data is estimated. In Regression (3), Dummy $\mathrm{t}_{\mathrm{t}}$ is a dummy variable that is coded as 1 if a firm-year belongs to Quintile 1, and 0 if a firm-year belongs to Quintile 5. If the coefficient on the interaction variable $\left(\beta_{3}\right)$ is statistically significant, the difference in persistence coefficients between Quintiles 1 and 5 is considered statistically significant.

$$
N I_{t+1}=\alpha+\beta_{1} \text { Dummy }_{t}+\beta_{2} N I_{t}+\beta_{3} \text { Dummy }_{t}{ }^{*} N I_{t}+\varepsilon_{t+1}
$$

In the same way, the methodology of Dichev and Tang (2009) is followed for testing differences in adjusted $\mathrm{R}^{2}$ across quintiles. This study uses a bootstrap test based on a simulation of the empirical distribution of the test statistic, assuming the null is true. In this case, the null hypothesis is that $I S_{\mathrm{t}}$ is unrelated to adjusted $\mathrm{R}^{2}$, and the test statistic is the difference in adjusted $\mathrm{R}^{2}$ between Quintiles 1 and 5. The empirical distribution under the null is simulated by randomly splitting the null sample (15,890 observations) into pseudo-ISt quintiles. Regression (2) is then run within pseudo-Quintiles 1 and 5 to obtain a difference in adjusted $\mathrm{R}^{2}$ between the two

\footnotetext{
${ }^{11}$ This paper uses the industry codes of the Securities Identification Code Committee in Japan, which relate to 33 different industries.

${ }^{12}$ For example, assume an industry-year that includes three firms (A, B, and C). If A's value of the proxy of Income-Smoothing $(\operatorname{Vol}(N I) / \operatorname{Vol}(P D I))$ is higher than those of the others and C's value is lower than those of the others, we rank A, B, and C as 1,2 , and 3 respectively, and divide each ranking by the number of observations in the industry-year. Therefore, $1 / 3,2 / 3$, and $3 / 3$ are the IS values of $\mathrm{A}, \mathrm{B}$, and $\mathrm{C}$, respectively.
} 
Table 1: Definitions of Types of Dividend Policies

\begin{tabular}{lcccc}
\hline \hline \multicolumn{5}{c}{ Future dividend policy } \\
\hline Nothing & From t to $\mathrm{t}+1$ & Our final sample size & From $\mathrm{t}+1$ to $\mathrm{t}+2$ & Our final sample size \\
Stable & $D P S_{t}=D P S_{t+1}=0$ & 1,844 & $D P S_{t+1}=D P S_{t+2}=0$ & 1,826 \\
Increase & $D P S_{t}=D P S_{t+1} \neq 0$ & 7,176 & $D P S_{t+1}=D P S_{t+2} \neq 0$ & 7,032 \\
Decrease & $D P S_{t}<D P S_{t+1}$ & 4,510 & $D P S_{t+1}<D P S_{t+2}$ & 4,428 \\
Omission & $D P S_{t}>D P S_{t+1}$ & 2,360 & $D P S_{t+1}>D P S_{t+2}$ & 2,604 \\
\hline
\end{tabular}

Note: $D P S_{t}$ is the dividend per share for Fiscal Year t.

quintiles. This difference is one observation from the simulated distribution under the null. This procedure is repeated 1,000 times, yielding a 1,000-observation empirical distribution of adjusted $\mathrm{R}^{2}$ differences under the null. The formal statistical test is based on a comparison of the actual observed difference in adjusted $\mathrm{R}^{2}$ against the simulated distribution of differences.

The second analysis is based on Model (4), following Tucker and Zarowin (2006).

$$
N I_{t+1}=\alpha+\beta_{1} N I_{t}+\beta_{2} I S_{t}+\beta_{3} N I^{*} I S_{t}+\varepsilon_{t+1}
$$

Although Model (4) looks similar to Model (3), the former adopts $I S_{\mathrm{t}}$ itself rather than a dummy variable. This model has the advantage of being able to test the relation between income smoothing behavior and future earnings persistence by using all observations. Of particular interest is the coefficient on $N I^{*} I S_{\mathrm{t}}$, which should be positive if income smoothing reflects future earnings persistence. ${ }^{13}$

$N I_{\mathrm{t}+1}$ may not be appropriate to estimate future stability because $N I_{\mathrm{t}+1}$ includes management discretion. To cope with this concern, we estimate model (5) in addition to model (4). In model (5), $P D I_{t+1}$ is used as the dependent variable. If management use their private information about future performance and inform their business stability through income smoothing, $P D I_{t+1}$ may be better proxy for future stability. In this model, we call $\beta_{1}$ "adjusted" earnings persistence.

$$
P D I_{t+1}=\alpha+\beta_{1} N I_{t}+\beta_{2} I S_{t}+\beta_{3} N I^{*} I S_{t}+\varepsilon_{t+1}
$$

\subsubsection{Dividend Policy}

This study explores the link between income smoothing and dividend policy in two ways. First, it compares the percentages of firms that have "no dividends," "stable dividends," "increase dividends," "decrease dividends", and "dividends omission" conditioning, based on $I S_{t}$ quintile. Second, logit regressions are run to investigate the relation between income smoothing in the past and future dividend policy.

This study classifies a firm's dividend policy as being in one of four categories: no dividends (Nothing), stable dividends (Stable), increase dividends (Increase), and decrease dividends (Decrease). In addition to these categories, we identify firm-years that omit dividends (Omission). This is because investors may be interested in future dividend omission. These five categories are defined in Table 1. Because Omission is the particular type of Decrease, the observations which are included in Omission also are included in Decrease.

\footnotetext{
${ }^{13}$ Instead of $N I_{t+1}$, Tucker and Zarowin (2006) use the sum of net income from $t+1$ to $t+3$ as the dependent variable. Although we use the same variable as the dependent variable, the results remain unchanged.
} 
In the logit regression analysis, several factors that affect a firm's dividend policy are controlled. If the $I S_{\mathrm{t}}$ factor is found to be statistically significant even after those factors are controlled, then the link between smoothing and dividend policy is considered significant. In Japanese corporate law, earnings available for dividends are determined on the basis of unconsolidated earnings. It seems, however, that consolidated earnings and consolidated payout ratios recently play an important role in the practice. Therefore we analyze the relation between income smoothing based on the consolidated earnings and dividends policy. Logit regression is run on Model (6).

$$
\begin{aligned}
& \left.Y_{\text {tor } t+1}=\alpha+\beta_{1} I S_{t}+\beta_{2} \text { Rank. ROA }_{t}+\beta_{3} \text { Rank. Growth }_{t}+\beta_{4} \text { Tobin' } Q_{t}+\beta_{5} \text { Rank.Vol}_{\text {PDI }}\right)_{t} \\
& +\beta_{6} \text { Size }_{t}+\beta_{7} \text { Foreign }_{t}+\beta_{8} \text { Financial }_{t}+\beta_{9} D_{-} i n c_{t}+\beta_{10} R E / B V E_{t} \\
& +\beta_{11} D_{-} \text {Nothing }_{t-1}+\beta_{12} \text { Stable }_{t-1}+\beta_{13} D_{-} \text {Increase }_{t-1}+\sum_{i=1995}^{2008} \text { Year dummy }_{i}+\varepsilon_{t}
\end{aligned}
$$

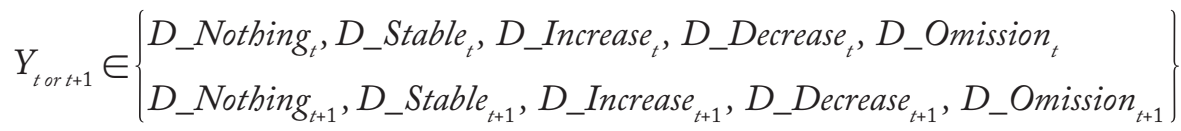

The dependent variables $\left(Y_{t o r} Y_{t+1}\right)$ comprise the following ten dummy variables, each of which

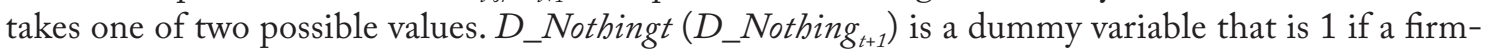
year's dividend policy from $\mathrm{t}(\mathrm{t}+1)$ to $\mathrm{t}+1(\mathrm{t}+2)$ is Nothing, and 0 otherwise. D_Stable ${ }_{t}\left(D_{-}\right.$ Stable $\left._{t+1}\right)$ is a dummy variable that is 1 if a firm-year's dividend policy from $t(t+1)$ to $t+1(t+$ $2)$ is Stable, and 0 otherwise. D_Increase ${ }_{t}\left(D_{-}\right.$Increase $\left._{t+1}\right)$ is a dummy variable that is 1 if a firmyear's dividend policy from $\mathrm{t}(\mathrm{t}+1)$ to $\mathrm{t}+1(\mathrm{t}+2)$ is Increase, and 0 otherwise. D_Decrease ${ }_{t}\left(D_{-}\right.$ Decrease $\left._{t+1}\right)$ is a dummy variable that is 1 if a firm-year's dividend policy from $t(t+1)$ to $t+1(t+$ 2 ) is Decrease, and 0 otherwise. Finally, D_Omission $\left(D_{-}\right.$Omission $\left._{t+1}\right)$ is a dummy variable that is 1 if a firm-year's dividend policy from $t(t+1)$ to $t+1(t+2)$ is Omission, and 0 otherwise.

The independent variables include the main variable $I S_{\mathrm{t}}$, as well as twelve other control variables. Denis and Osobov (2008) report that the propensity to pay dividends is higher among firms that are larger, are more profitable, and have higher retained earnings. In order to control for the effect these factors have on dividend policy, the natural logarithm of market value of equity at the end of Fiscal Year $\mathrm{t}\left(\right.$ Size $\left._{t}\right)$ is added, along with net income before extraordinary income in Fiscal Year $t$ divided by total assets at the beginning of Fiscal Year $t\left(R O A_{t}\right)$, and retained earnings divided by book value of equity at the end of Fiscal Year $t\left(R E / B V E_{t}\right)$. In addition, an earnings growth dummy $\left(D_{-} i n c_{t}\right)$ is added; it takes a value of 1 if a firm reports positive earnings growth for Fiscal Year t, and 0 otherwise, because it is possible that the earnings growth affects the firm's dividend policy. According to the lifecycle hypothesis vis-à-vis dividends, high-growth firms tend to retain earnings for reinvesting, thus leading such firms to take a no-dividends strategy. In contrast, the propensity to pay stable dividends or increase dividends is higher among low-growth, relatively mature firms. Firms in a declination stage would decrease dividends. The geometric average of the five-year sales growth rate (from Fiscal Year t-4 to $\mathrm{t}$ ) is a proxy for past growth $\left(\right.$ Growth $_{t}$ ). Tobin's $Q_{t}$ is a proxy variable for investment opportunity in the future. Tobin's $Q_{t}$ is defined as the ratio of the sum of the market value of equity and book value of total debt, to the sum of the book value of equity and total debt at the end of Fiscal Year t. PDI volatility $\left(\operatorname{Vol}_{t}(P D I)_{t}\right)$ is added as a control variable, because managers are sensitive about performance uncertainty when 
making decisions about payouts. The survey of Brav et al. (2005) shows that institutional investors affect dividends. Here, the equity ownership percentage of financial institutions at the end of Fiscal

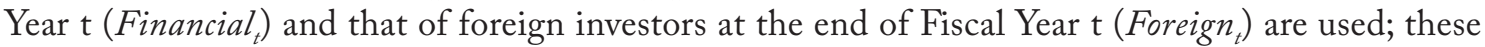
two factors may function as discipline for Japanese managers and facilitate aggressive payouts. In addition, we include $D \_$Nothing $_{t-1}, D \_$Stable $_{t-1}$, and D_Increase ${ }_{t-1}$ in Model (6) in order to control for the effect of past dividend policy.

Considering the effects of industry and year on profitability, growth, and uncertainty, $R O A_{t}$, Growth, and $\operatorname{Vol}(P D I)_{t}$ are adjusted. These variables are ranked in ascending order within its industry-year and divided by the number of observations in each industry-year. This study defines these as Rank.ROA ${ }_{t}$, Rank.Growth ${ }_{t}$, and Rank.Vol(PDI) ${ }_{t}{ }^{14}$ Moreover, to control other year effects, we include year dummies in the model.

In this study, all t-statistics and z-statistics are corrected for heteroskedasticity, and crosssectional and time-series dependence using a two-way cluster at the firm and year level proposed by Petersen (2009) and Cameron et al. (2011)..$^{15}$

\subsection{Sample}

The empirical analysis is based on Japanese non-financial firms over the 1990-2010 period. The initial sample includes 59,261 firm-years. Data are basically screened according to the following criteria (figure in parentheses represents sample size after each criterion):

(1) The firms have to be Japanese listed firms (59,261 firm-years).

(2) Fiscal Year-end should be March (43,498 firm-years).

(3) The firms should be compliant with Japanese accounting standards (42,928 firm-years).

(4) All data must be available for $D A C$ estimation (40,259 firm-years).

(5) To ensure that the results are not outlier-sensitive, variables in the top and bottom 0.5 percent have been eliminated from the Model (1) estimation (38,599 firm-years).

(6) Firms in the industry-year with more than 10 firms (38,078 firm-years)

(7) All financial and market data are available $(19,558 \text { firm-years })^{16}$

(8) Change in number of shares outstanding (from $t$ to $t+1, t+1$ to $t+2$ ) is within 20 percent $^{17}$ (17,947 firm-years)

(9) To ensure that the results are not sensitive to outliers, except for dummy variables, variables in the top and bottom 0.5 percent have been eliminated in Models (2), (4), (5) and (6) estimation ${ }^{18}$ (15,890 firm-years).

Through the use of these criteria, a final sample of 15,890 firm-year observations is generated. ${ }^{19}$

${ }^{14}$ Even when unranked $R O A_{t}$, unranked Growth, and unranked $V_{0}(P D I)_{t}$ are used instead of Rank.ROA, Rank. Growth, and Rank. $\operatorname{Vol}(P D I)$, the empirical results remain unchanged.

${ }^{15}$ If clustering of the standard errors does not allow for the inclusion of all of our currently included year dummy variables, we combine at least two year dummy variables into one year dummy variable in order to estimate the regression.

${ }^{16}$ This criteria dramatically reduces the sample size. This is mainly because the calculation of our fourth income smoothing measure (see section 5) requires current and past five years' net income before accrual discretion and $D A C$ (from year $\mathrm{t}-5$ to $\mathrm{t}$ ) in order to calculate the measure for year $\mathrm{t}$, and dividend policy measures (from year $\mathrm{t}+1$ to $\mathrm{t}+2$ ) require both $D P S_{t+1}$ and $D P S_{t+2}$ in calculation.

${ }^{17}$ Following Ishikawa (2007), we adopt this criteria.

${ }^{18}$ Even when we skip criteria (9), the empirical results remain unchanged.

${ }^{19}$ The top and bottom 0.5 percent of the regression variables are truncated twice (i.e., criteria (5) and (9)), not only to prevent outliers from affecting estimations of Regression (1), but also to obtain a large sample to test the hypotheses. To mitigate the effect of a change in the number of shares outstanding on dividends per share, criterion (8) is included. In addition, instead of using Rank. $R O A_{t}$, Rank.Growth ${ }_{t}$, and Rank.Vol(PDI), to delete outliers, the $R O A_{t}$, Growth $_{t}$, and Vol(PDI), values are used. 
Figure 1: Distribution of Dividend Policy


$D P S_{t}=$ the dividend per share for Fiscal Year $\mathrm{t}$.

Nothing means a firm-year without any dividend for both Fiscal Year $\mathrm{t}$ and Fiscal Year $\mathrm{t}+1$. Stable means a firm-year paying as much DPS for Fiscal Year $\mathrm{t}+1$ as Fiscal Year $\mathrm{t}$.

Increase means a firm-year paying more DPS for Fiscal Year $\mathrm{t}+1$ than DPS for Fiscal Year $\mathrm{t}$.

Decrease means a firm-year paying less DPS for Fiscal year $\mathrm{t}+1$ than Fiscal Year $\mathrm{t}$.

Table 2 provides descriptive statistics. Table 3 presents a correlation matrix of variables used in OLS and logit regressions. At first glance, high correlations are observed between Size $_{t}$ and Tobin's $Q_{t}$, Size t $_{t}$ and Foreign, and Size ${ }_{t}$ and Financial. To cope with multicollinearity issues, regressions are run in advance, with either variable alone, on Models (6). The results remain the same. ${ }^{20}$ Hence, all these variables are, hereafter, included in the logit regression analysis.

Figure 1 presents distribution of dividend policy over the period 1995-2009. We can observe interesting dividend policies of Japanese firms. First, there are very few "Nothing". Approximately, ninety percent of firms pay dividends. Second, during 2002-2007, Japanese economy enjoyed booming, which resulted in more "Increase" and less "Decrease". Third, in 2008-2009, world financial crisis caused more "Decrease" and less "Increase". Fourth, and most importantly, it should be noted that percentage share of "Stable" is stable. The share ranges from 37.7 and 53.3 percent. Even after world financial crisis in 2008, 39.3 percent of Japanese firms did not change their DPS.

${ }^{20}$ Furthermore, we calculate the VIF in the logit regression of $D \_S t a b l e ~ e_{t+1}$. The results show that D_Increase $e_{t-1}$ has the highest VIF value (2.77). Considering the value of VIF under 10, there exists little concern about multicollinearity problem. 
Table 2: Descriptive Statistics (Observations during 1995 - 2008)

\begin{tabular}{|c|c|c|c|c|c|c|c|c|}
\hline & Mean & Std.dev. & Min & $25 \%$ & Median & $75 \%$ & Max & $\mathrm{N}$ \\
\hline$N I_{t}$ & 0.016 & 0.029 & -0.134 & 0.004 & 0.015 & 0.031 & 0.124 & 15,890 \\
\hline $\operatorname{Vol}(N I)_{t}$ & 0.017 & 0.015 & 0.000 & 0.007 & 0.012 & 0.022 & 0.185 & 15,890 \\
\hline$P D I_{t}$ & 0.015 & 0.050 & -0.165 & -0.015 & 0.015 & 0.045 & 0.195 & 15,890 \\
\hline $\operatorname{Vol}(P D I)_{t}$ & 0.044 & 0.024 & 0.008 & 0.026 & 0.038 & 0.055 & 0.158 & 15,890 \\
\hline $\operatorname{Vol}(N I) / \operatorname{Vol}(P D I)_{t}$ & 0.443 & 0.353 & 0.024 & 0.185 & 0.348 & 0.604 & 2.559 & 15,890 \\
\hline$R O A_{t}$ & 0.024 & 0.027 & -0.164 & 0.009 & 0.021 & 0.038 & 0.172 & 15,890 \\
\hline Growth & -0.004 & 0.044 & -0.148 & -0.032 & -0.005 & 0.022 & 0.170 & 15,890 \\
\hline Size $_{t}$ & 10.071 & 1.46 & 6.85 & 9.01 & 9.92 & 10.99 & 14.23 & 15,890 \\
\hline Tobin's $Q_{t}$ & 1.063 & 0.311 & 0.480 & 0.866 & 1.007 & 1.187 & 2.998 & 15,890 \\
\hline$R E / B V E_{t}$ & 0.364 & 0.351 & -3.054 & 0.067 & 0.419 & 0.623 & 0.952 & 15,890 \\
\hline Foreign $_{t}$ & 0.062 & 0.078 & 0.000 & 0.007 & 0.028 & 0.091 & 0.417 & 15,890 \\
\hline Financial $_{t}$ & 0.282 & 0.143 & 0.013 & 0.168 & 0.267 & 0.388 & 0.648 & 15,890 \\
\hline$D P S_{t}$ & 22.2 & 234.7 & 0 & 4 & 7.5 & 12 & 8,400 & 15,890 \\
\hline
\end{tabular}

$N I_{t}=$ the net income for Fiscal Year $\mathrm{t}$, deflated by the total assets at the beginning of Fiscal Year $\mathrm{t}$.

$\operatorname{Vol}(N I)_{t}=$ the firm-specific volatility of earnings that is calculated as the standard deviation of NI over the most recent five years.

$T A C_{t}=$ total accrual that is defined as (change in current assets - change in cash and cash equivalents) - (change in liabilities - change in financing item) - change in other allowance - depreciation for Fiscal Year $t$, deflated by the total assets at the beginning of Fiscal Year $t$.

$N D A C_{t}=$ non discretionary accrual that is estimated by using Kothari et al. (2005) 's model.

$D A C_{t}=$ discretionary accrual that is definded by $T A C_{t}$ minus $N D A C_{t}$.

$A T R D_{t}=$ real discretion after tax that is definded by the gain/loss on the sale of marketable securities reported in extraordinary items at Fiscal Year $t$ multiplied by 0.6 , deflated by the total assets at the beginning of Fiscal Year $t$.

$P D I_{t}=$ the pre-discretionary income that is defined as $N I_{t}$ minus both $D A C_{t}$ and $A T R D_{t}$ Fiscal Year t.

$\operatorname{Vol}(P D I)_{t}=$ the firm-specific volatility of $P D I$ that is calculated as the standard deviation of $P D I$ over the most recent five years.

$\operatorname{Vol}(\mathrm{NI}) /=$ the ratio of $\operatorname{Vol}(N I)_{t}$ to $\operatorname{Vol}(P D I)_{t}$

$R O A_{t}=$ the ratio of net income before extraordinary items for Fiscal Year $\mathrm{t}$ over total assets at the beginning of Fiscal Year t.

Growth $_{t}=$ the geometric average of the sales growth rate from Fiscal Year $\mathrm{t}-4$ to Fiscal Year $\mathrm{t}$.

Size $_{t}=$ the natural logarithm of the market value at the end of Fiscal Year $\mathrm{t}$.

Tobin's $Q_{t}=$ the ratio of the sum of the market value and total debt to the sum of the book value of equity and total debt at the end of Fiscal Year $t$.

$R E / B V E_{t}=$ the ratio of the retained earnings to the book value of equity at the end of Fiscal Year $\mathrm{t}$.

Foreign $_{t}=$ the foreign ownership at the end of Fiscal Year $\mathrm{t}$.

Financial $_{t}=$ the financial institute ownership at the end of Fiscal Year t.

$D P S_{t}=$ the dividend per share for Fiscal Year $\mathrm{t}$. 





Table 4: Comparison of Vol(NI) and Vol(PDI) Across Quintiles

\begin{tabular}{ccccccccc}
\hline \hline Quintiles by $I S_{t}$ & \multicolumn{3}{c}{ Vol(NI) } & \multicolumn{3}{c}{$\operatorname{Vol}_{t}(\mathrm{PDI})_{t}$} \\
\hline & $\mathrm{N}$ & Mean & Std.Dev Median & Mean & Std.Dev Median \\
Quintle 1 & 3,178 & 0.032 & 0.021 & 0.028 & 0.034 & 0.020 & 0.030 \\
Quintle 2 & 3,178 & 0.021 & 0.014 & 0.018 & 0.039 & 0.021 & 0.035 \\
Quintle 3 & 3,178 & 0.016 & 0.010 & 0.013 & 0.043 & 0.022 & 0.039 \\
Quintle 4 & 3,178 & 0.011 & 0.007 & 0.009 & 0.046 & 0.023 & 0.041 \\
Quintle 5 & 3,178 & 0.006 & 0.004 & 0.005 & 0.054 & 0.026 & 0.048 \\
\hline Difference (Quintile 5 - Quintile 1) & -0.026 & & -0.022 & 0.020 & & 0.018 \\
p-value on difference & & $<0.001$ & & $<0.001$ & $<0.001$ & & $<0.001$ \\
\hline
\end{tabular}

$N I_{t}=$ the net income for Fiscal Year $\mathrm{t}$, deflated by the total assets at the beginning of Fiscal Year $\mathrm{t}$.

$\operatorname{Vol}(N I)_{t}=$ the firm-specific volatility of earnings that is calculated as the standard deviation of $N I$ over the most recent five years.

$T A C_{t}=$ total accrual that is defined as (change in current assets - change in cash and cash equivalents) - (change in liabilities - change in financing item) - change in other allowance - depreciation for Fiscal Year $t$, deflated by the total assets at the beginning of Fiscal Year $t$.

$N D A C_{t}=$ non discretionary accrual that is estimated by using Kothari et al. (2005) 's model.

$D A C_{t}=$ discretionary accrual that is definded by $T A C_{t}$ minus $N D A C_{t}$.

$A T R D_{t}=$ real discretion after tax that is definded by the gain/loss on the sale of marketable securities reported in extraordinary items at Fiscal Year t multiplied by 0.6 , deflated by the total assets at the beginning of Fiscal Year $t$.

$P D I_{t}=$ the pre-discretionary income that is defined as $N I_{t}$ minus both $D A C_{t}$ and $A T R D_{t}$ for Fiscal Year t.

$\operatorname{Vol}(P D I)_{t}=$ the firm-specific volatility of $P D I$ that is calculated as the standard deviation of $P D I$ over the most recent five years.

Quintile 1 is the lowest $I S$ (least income smoothing) quintile, and Quintile 5 is the highest $I S$ (most income smoothing) quintile. The $\mathrm{p}$-value for the difference in mean values across quintiles is derived from a $\mathrm{t}$-test. The $\mathrm{p}$-value for the difference in median values across quintiles is derived from a Mann-Whitney test.

\section{Results}

\subsection{Income Smoothing Behavior and Volatility}

Table 4 compares $N I$ volatility and $P D I$ volatility conditioning, in terms of $I S_{t}$ quintiles. Firms in Quintile 1 have the lowest $I S_{t}$ (i.e., least income smoothing), while firms in Quintile 5 have the highest $I S_{t}$ (i.e., most income smoothing). The results clearly indicate the effect of smoothing behavior. Quintile 5 has the highest volatility of pre-discretionary income (0.054) before its earnings management; the firms in there, however, have the most-smoothed reported net income (0.006), compared to those in Quintile 1 (0.032). It is clear that firms in Quintile 5 try to control PDI volatility via smoothing and successfully reduce the volatility of reported NI.

\subsection{Income Smoothing Behavior and Earnings Persistence}

The regression results of Model (2) are reported in Table 5. Earnings persistence coefficients, $\beta$, increase from Quintile 1 to Quintile 5. It is worth noting that the difference of persistence between Quintile 5 and Quintile 1 (0.871 and 0.425 , respectively) is statistically significant at the 0.1 percent 
Table 5: Results for The Earnings Persistence Regression in Model (2)

\begin{tabular}{|c|c|c|c|c|c|c|}
\hline \multirow[t]{2}{*}{ Quintiles by $I S_{t}$} & \multicolumn{2}{|c|}{$\alpha$} & \multicolumn{2}{|c|}{$\beta$} & \multirow{2}{*}{ Adj. $R^{2}$} & \multirow{2}{*}{$\mathrm{N}$} \\
\hline & Coefficient & t-value & Coefficient & $\mathrm{t}$-value & & \\
\hline Quintle 1 & 0.009 & $3.54^{* * * *}$ & 0.425 & $14.46^{* * * *}$ & 0.232 & 3,178 \\
\hline Quintle 2 & 0.005 & $2.12^{* *}$ & 0.552 & $17.55^{\text {**** }}$ & 0.285 & 3,178 \\
\hline Quintle 3 & 0.003 & 1.56 & 0.665 & $12.64^{* * * *}$ & 0.333 & 3,178 \\
\hline Quintle 4 & 0.000 & -0.21 & 0.799 & $12.75^{\text {**** }}$ & 0.354 & 3,178 \\
\hline Quintle 5 & -0.002 & -1.07 & 0.871 & $17.94^{* * *}$ & 0.385 & 3,178 \\
\hline \multirow{2}{*}{\multicolumn{3}{|c|}{ Difference (Quintile 5 - Quintile 1) }} & 0.446 & & 0.152 & \\
\hline & & & $<0.001$ & & $<0.001$ & \\
\hline
\end{tabular}

$N I_{t}=$ the net income for Fiscal Year $\mathrm{t}$, deflated by the total assets at the beginning of Fiscal Year $\mathrm{t}$.

$\operatorname{Vol}(N I)_{t}=$ the firm-specific volatility of earnings that is calculated as the standard deviation of NI over the most recent five years.

$T A C_{t}=$ total accrual that is defined as (change in current assets - change in cash and cash equivalents) (change in liabilities - change in financing item) - change in other allowance - depreciation for Fiscal Year t, deflated by the total assets at the beginning of Fiscal Year $t$.

$N D A C_{t}=$ non discretionary accrual that is estimated by using Kothari et al. (2005) 's model.

$D A C_{t}=$ discretionary accrual that is definded by $T A C_{t}$ minus $N D A C_{t}$.

$A T R D_{t}=$ real discretion after tax that is definded by the gain/loss on the sale of marketable securities reported in extraordinary items at Fiscal Year t multiplied by 0.6 , deflated by the total assets at the beginning of Fiscal Year t.

$P D I_{t}=$ the pre-discretionary income that is defined as $N I_{t}$ minus both $D A C_{t}$ and $A T R D_{t}$ for Fiscal Year t.

$\operatorname{Vol}(P D I)_{t}=$ the firm-specific volatility of $P D I$ that is calculated as the standard deviation of PDI over the most recent five years.

$\operatorname{Vol}(N I) / \operatorname{Vol}(P D I)_{t}=$ the ratio of $\operatorname{Vol}(N I) t$ to $\operatorname{Vol}(P D I)_{t}$

$I S_{t}=$ the within industry-year reversed fractional ranking (between 0 and 1) of $\operatorname{Vol}(N I) /$ $\operatorname{Vol}(P D I)$ for Fiscal Year $\mathrm{t}$ (see text for full details).

Quintile 1 is the lowest $I S$ (least income smoothing) quintile, and Quintile 5 is the highest $I S$ (most income smoothing) quintile. The $\mathrm{p}$-value for the difference in persistence coefficients across quintiles is derived from a t-test. The p-value for the difference in the Adj. $\mathrm{R}^{2}$ across quintiles is derived from a bootstrap test (see text for full details). All t-statistics are corrected for heteroskedasticity, and cross-sectional and time-series correlation using a two-way cluster at the firm and year level proposed by Petersen (2009).

***, **, and * indicate significance at $1 \%, 5 \%$, and $10 \%$, respectively.

level. It would be reasonable to conclude that there is a positive relation between income smoothing behavior in the past and future earnings persistence.

Table 6 indicates the results of regression, for the full sample, on Model (4). Consistent with the results of Tucker and Zarowin (2006), the coefficient of the intersection term, $N I{ }^{*} I S_{t}$, is positive and statistically significant at the 1 percent level. This result again implies that a manager's smoothing behavior in the five previous years relates positively to earnings persistence for future periods. This evidence reinforces the results found in Table $5 .{ }^{21}$ Even when we use $P D I_{t+1}$ as the dependent variable instead of $N I_{t+1}$ (Table 7), these results remain unchanged. In the light of these results, it seems that income smoothing behaviors in the past succeed in exhibiting future earnings persistence.

\footnotetext{
${ }^{21}$ When we analyze the relation between income smoothing measures that are based on $D A C$ (i.e. IS2 and IS4, see also section 5) and $R O A$ persistence, the tenor of the results remains unchanged.
} 


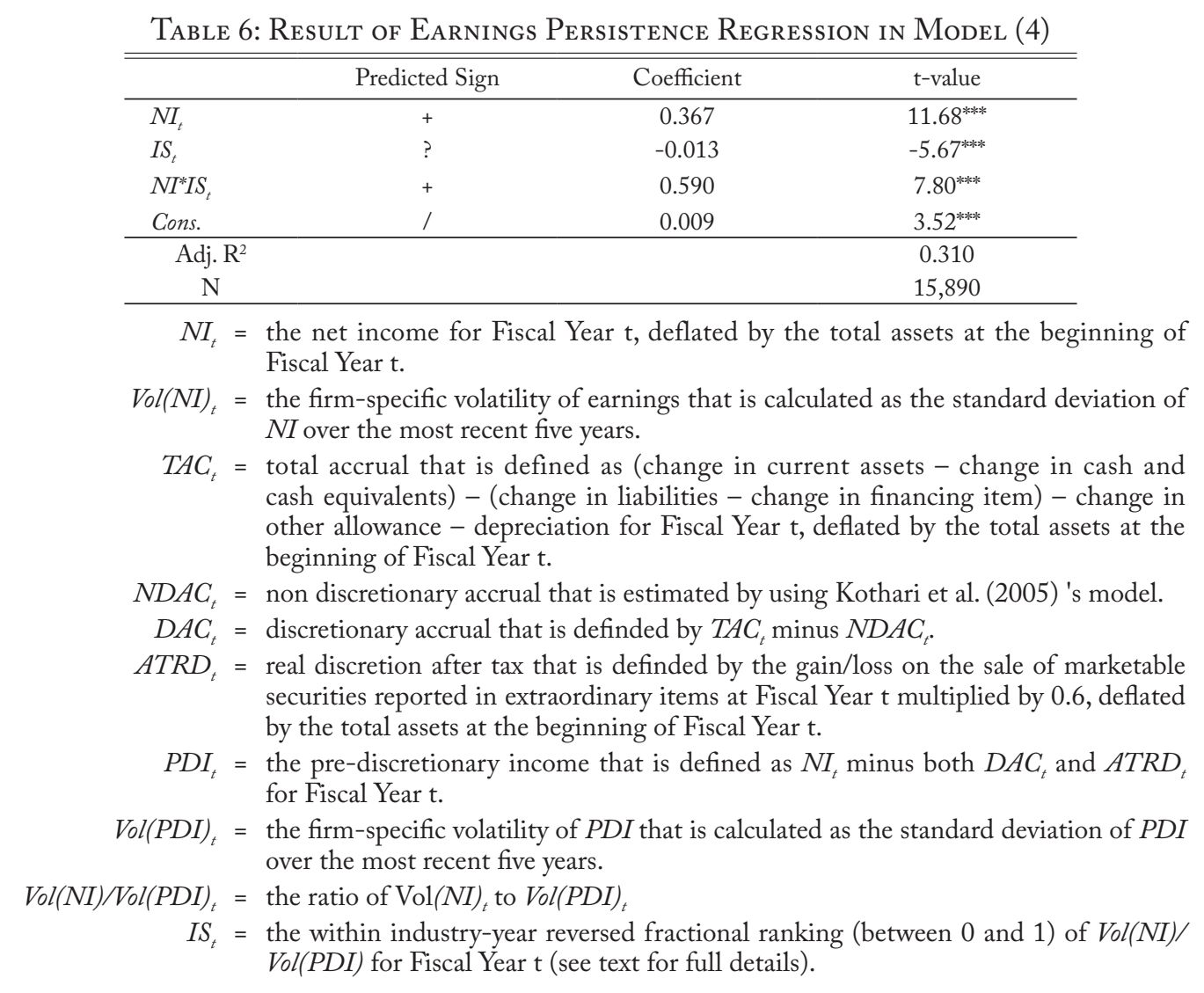

\footnotetext{
$N I^{*} I S_{t}$ is the interaction term, which is defined as $N I_{t} \times I S_{t}$. All t-statistics are corrected for heteroskedasticity, and crosssectional and time-series correlation using a two-way cluster at the firm and year level proposed by Petersen (2009).

**** indicates significance at $1 \% . "$
}

\subsection{Income Smoothing Behavior and Dividend Policy}

Table 8 indicates firms' dividend policies, by $I S_{t}$ quintile. With regard to the period $\mathrm{t} \sim \mathrm{t}+1$ (Panel A), the most income-smoothing Quintile 5 includes the least number of no-dividend firms (4.9 percent), dividend omission firms (2.7 percent), and the greatest number of stable-dividend firms (53.7 percent). The difference between Quintiles 5 and 1 ( -16.0 percent, -1.3 percent, and 17.7 percent, respectively) is statistically significant at the 1 percent level. For the period $t+1 \sim t+2$ (Panel B), reported on the bottom half of Table 8 , similar patterns are observed. Higher-smoothing firms have a tendency to pay stable dividends in the future, and they seldom adopt a no-dividends or dividend omission policy. With regard to Increase, lower-smoothing firms have a moderate tendency to adopt dividends increase policy compared to higher-smoothing firms. This trend might imply that managers smooth income to avoid increasing dividends in the future. Meanwhile, income smoothing in the past period has no effect on a future dividends decrease. 


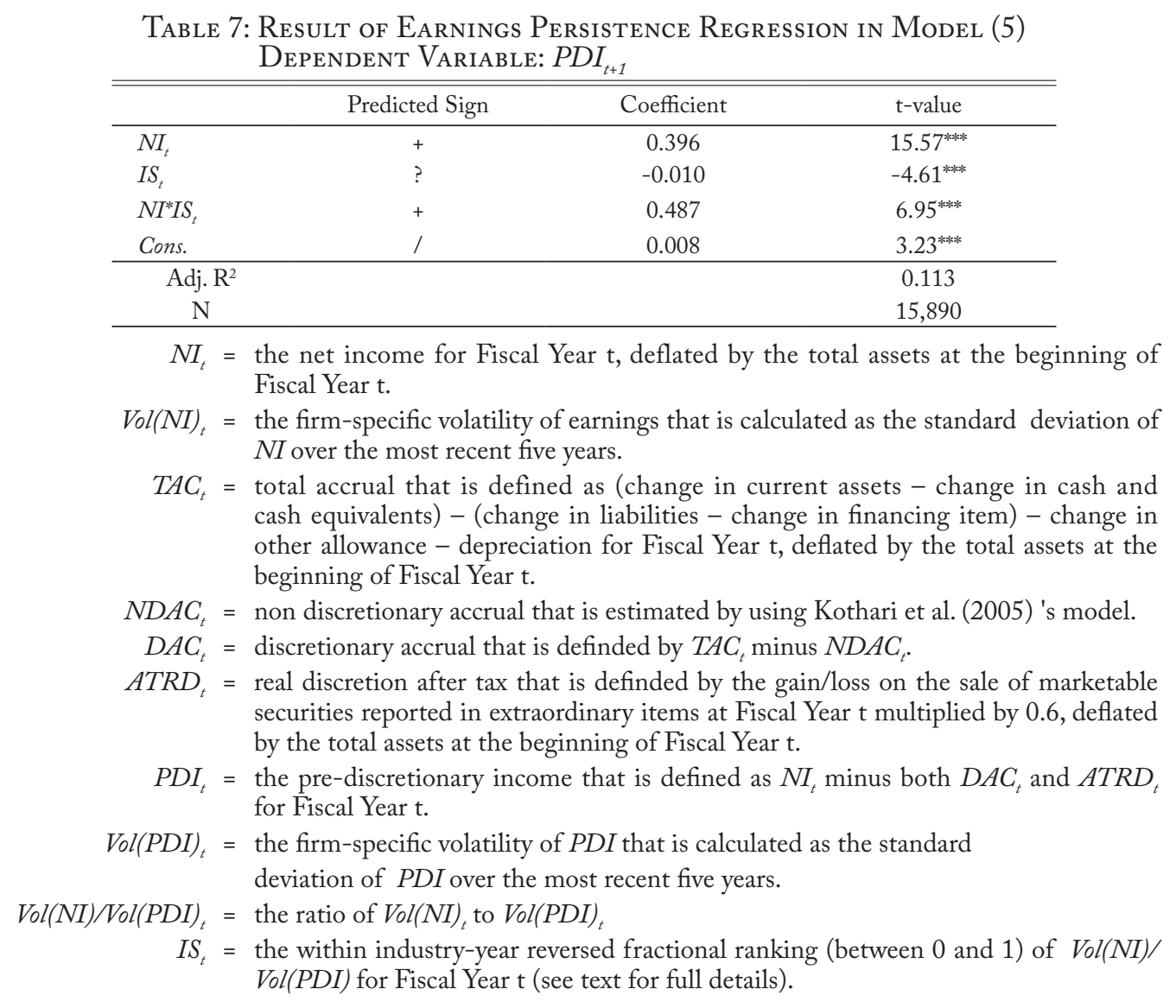

\begin{abstract}
$N I^{*} I S_{t}$ is the interaction term, which is defined as $N I_{t} \times I S_{t}$. All t-statistics are corrected for heteroskedasticity, and crosssectional and time-series correlation using a two-way cluster at the firm and year level proposed by Petersen (2009).

**** indicates significance at $1 \%$."
\end{abstract}

Table 9 presents the results of logit regression, for the full sample, on Model (6). ${ }^{22}$ This table shows the results with fully controlled variables. $I S_{t}$ has a negative impact on Nothing and Omission. Meanwhile, it has a positive and statistically significant effect on Stable. The results of the current analysis clearly indicate that income smoothing has a negative association with both a no-dividends policy and a dividend omission policy and a positive association with a stable-dividends strategy. Even when several possible fundamental factors and corporate governance factors are being controlled, $I S_{t}$ remains significant, in both the $t$ to $t+1$ window and the $t+1$ to $t+2$ window. Financial $t$ and Foreign $n_{t}$ negatively relate to Nothing; this may have been due to the "prudent man" investment restrictions on institutional investors (Brav et al.

\footnotetext{
${ }^{22}$ In some model, observations' number is not 15,890 . This is because, in these models, some independent variables' values can fit dependent variable values perfectly (e.g. observations whose $D \_S t a b l e ~ t$ equal to one can fit $D \_N o t h i n g$ that equals to zero perfectly). Therefore, we have to drop these observations in the estimation.
} 
Table 8: Comparison of Dividend Policy Across IS Quintiles

\begin{tabular}{|c|c|c|c|c|c|c|c|c|c|c|c|}
\hline \multicolumn{12}{|c|}{ Panel A: Comparison of Dividend Policy (from t to $t+1)$ Across IS Quintiles } \\
\hline \multirow{2}{*}{\multicolumn{2}{|c|}{ Quintiles by $I S_{t}$}} & \multicolumn{10}{|c|}{ Dividend policy from $t$ to $t+1$} \\
\hline & & \multicolumn{2}{|c|}{ Nothing } & \multicolumn{2}{|c|}{ Stable } & \multicolumn{2}{|c|}{ Increase } & \multicolumn{2}{|c|}{ Decrease } & \multicolumn{2}{|c|}{ Omission } \\
\hline & $\mathrm{N}$ & Number & $\%$ & Number & $\%$ & Number & $\%$ & Number & $\%$ & Number & $\%$ \\
\hline Quintile 1 & 3,178 & 663 & $20.9 \%$ & 1142 & $35.9 \%$ & 929 & $29.2 \%$ & 444 & $14.0 \%$ & 125 & $3.9 \%$ \\
\hline Quintile 2 & 3,178 & 464 & $14.6 \%$ & 1321 & $41.6 \%$ & 909 & $28.6 \%$ & 484 & $15.2 \%$ & 121 & $3.8 \%$ \\
\hline Quintile 3 & 3,178 & 321 & $10.1 \%$ & 1482 & $46.6 \%$ & 902 & $28.4 \%$ & 473 & $14.9 \%$ & 99 & $3.1 \%$ \\
\hline Quintile 4 & 3,178 & 240 & $7.6 \%$ & 1525 & $48.0 \%$ & 916 & $28.8 \%$ & 497 & $15.6 \%$ & 91 & $2.9 \%$ \\
\hline Quintile 5 & 3,178 & 156 & $4.9 \%$ & 1706 & $53.7 \%$ & 854 & $26.9 \%$ & 462 & $14.5 \%$ & 85 & $2.7 \%$ \\
\hline \multicolumn{3}{|c|}{$\begin{array}{c}\text { Difference } \\
\text { (Quintile 5 - Quintile 1) }\end{array}$} & $-16.0 \%$ & & $17.7 \%$ & & $-2.4 \%$ & & $0.6 \%$ & & $-1.3 \%$ \\
\hline \multicolumn{3}{|c|}{ p-value on difference } & $<0.001$ & & $<0.001$ & & 0.036 & & 0.518 & & 0.005 \\
\hline
\end{tabular}

Panel B: Comparison of Dividend Policy (from $t+1$ to $t+2)$ Across IS Quintiles

\begin{tabular}{|c|c|c|c|c|c|c|c|c|c|c|c|}
\hline \multirow{2}{*}{\multicolumn{2}{|c|}{ Quintiles by $I S_{t}$}} & \multicolumn{10}{|c|}{ Dividend policy from $t+1$ to $t+2$} \\
\hline & & \multicolumn{2}{|c|}{ Nothing } & \multicolumn{2}{|c|}{ Stable } & \multicolumn{2}{|c|}{ Increase } & \multicolumn{2}{|c|}{ Decrease } & \multicolumn{2}{|c|}{ Omission } \\
\hline & $\mathrm{N}$ & Number & $\%$ & Number & $\%$ & Number & $\%$ & Number & $\%$ & Number & $\%$ \\
\hline Quintile 1 & 3,178 & 641 & $20.2 \%$ & 1136 & $35.7 \%$ & 892 & $28.1 \%$ & 509 & $16.0 \%$ & 148 & $4.7 \%$ \\
\hline Quintile 2 & 3,178 & 444 & $14.0 \%$ & 1360 & $42.8 \%$ & 866 & $27.2 \%$ & 508 & $16.0 \%$ & 132 & $4.2 \%$ \\
\hline Quintile 3 & 3,178 & 315 & $9.9 \%$ & 1438 & $45.2 \%$ & 911 & $28.7 \%$ & 514 & $16.2 \%$ & 107 & $3.4 \%$ \\
\hline Quintile 4 & 3,178 & 247 & $7.8 \%$ & 1463 & $46.0 \%$ & 920 & $28.9 \%$ & 548 & $17.2 \%$ & 109 & $3.4 \%$ \\
\hline Quintile 5 & 3,178 & 179 & $5.6 \%$ & 1635 & $51.4 \%$ & 839 & $26.4 \%$ & 525 & $16.5 \%$ & 103 & $3.2 \%$ \\
\hline \multicolumn{3}{|c|}{$\begin{array}{c}\text { Difference } \\
\text { (Quintile 5 - Quintile 1) }\end{array}$} & $-14.5 \%$ & & $15.7 \%$ & & $-1.7 \%$ & & $0.5 \%$ & & $-1.4 \%$ \\
\hline \multicolumn{3}{|c|}{$\mathrm{p}$-value on difference } & $<0.001$ & & $<0.001$ & & 0.135 & & 0.587 & & 0.004 \\
\hline
\end{tabular}

Quintile 1 is the lowest $I S$ (least income smoothing) quintile, and Quintile 5 is the highest $I S$ (most income smoothing) quintile.

$D P S_{t}=$ the dividend per share for Fiscal Year $\mathrm{t}$.

Nothing means a firm-year without any dividend for both Fiscal Year $\mathrm{t}(\mathrm{t}+1)$ and Fiscal Year $\mathrm{t}+1(\mathrm{t}+2)$.

Stable means a firm-year paying as much DPS for Fiscal Year $\mathrm{t}+1(\mathrm{t}+2)$ as Fiscal Year $\mathrm{t}(\mathrm{t}+1)$.

Increase means a firm-year paying more DPS for Fiscal Year $\mathrm{t}+1(\mathrm{t}+2)$ than DPS for Fiscal Year $\mathrm{t}(\mathrm{t}+1)$.

Decrease means a firm-year paying less DPS for Fiscal year $\mathrm{t}+1(\mathrm{t}+2)$ than Fiscal Year $\mathrm{t}(\mathrm{t}+1)$.

Omission means a firm-year omitting dividends for Fiscal year $t+1(t+2)$.

The $\mathrm{p}$-value for the difference in percentages across quintiles is derived from a chi-square test.

2005). As for Increase and Decrease, IS has a negative effect on Increase, but this effect is not so powerful. Moreover, there is no statistically significant effect on Decrease. Our results might suggest managers' income smoothing relates to avoidance of future dividends increase.

The results of our two tests (earnings persistence and dividend policy) indicate income smoothing behavior is likely to reflect future stability of earnings performance. Therefore, outsiders could consider a manager's income smoothing behavior as a signal about the firm's future stability of performance. 
Table 9: Tests of Relation Between Income Smoothing and Dividend Policy

\begin{tabular}{|c|c|c|c|c|c|c|c|c|c|c|}
\hline & Divide & d policy fro & $\mathrm{m} t$ to $\mathrm{t}+1$ & & & & Sividend po & olicy from $t$ & $t+1$ to $t+2$ & \\
\hline & & & $\begin{array}{c}\text { Coefficien } \\
\text { z-value }\end{array}$ & & & & & $\begin{array}{c}\text { Coefficient } \\
\text { z-value }\end{array}$ & & \\
\hline & D_Nothing & D_Stable & D_Increase & D_Decrease & D_Omission & D_Nothing & D_Stable & D_Increase & D_Decrease & D_Omission \\
\hline Cons & 1.338 & -0.427 & -2.955 & 0.338 & -0.459 & 1.856 & -0.703 & -2.382 & -1.045 & -2.066 \\
\hline & $1.98^{* *}$ & -1.470 & $-14.68^{* * * *}$ & 1.20 & -0.57 & $4.39^{* * * *}$ & $-2.11^{* *}$ & $-9.03^{* * *}$ & $-3.50^{* * * *}$ & -2.59 **** \\
\hline$I S_{t}$ & -0.675 & 0.362 & -0.172 & -0.128 & -0.711 & -0.665 & 0.352 & -0.121 & -0.083 & -0.465 \\
\hline & $-2.49^{* *}$ & $4.02^{\text {**** }}$ & $-1.65^{*}$ & -1.05 & $-3.08^{\text {***** }}$ & $-3.15^{* * *}$ & $3.83^{* * * *}$ & -0.94 & -1.07 & -2.54 *** \\
\hline Rank.ROA & -1.914 & 0.000 & 1.102 & -1.223 & -2.816 & -2.204 & 0.264 & 0.496 & -0.177 & -2.025 \\
\hline & $-8.15^{* * * *}$ & 0.00 & $14.20^{\text {**** }}$ & $-7.59^{* * * *}$ & $-11.82^{* * * *}$ & $-7.86^{* * *}$ & $2.00^{* *}$ & $5.16^{* * *}$ & -0.97 & $-10.35^{\text {**** }}$ \\
\hline Rank.Growth & -0.192 & -0.040 & 0.232 & -0.208 & -0.001 & -0.022 & -0.089 & 0.165 & -0.035 & 0.172 \\
\hline & -1.22 & -0.44 & $2.58^{\text {***** }}$ & $-2.14^{* *}$ & -0.01 & -0.16 & -1.48 & $2.17^{* *}$ & -0.45 & 1.21 \\
\hline Tobin's $Q_{t}$ & 1.050 & -0.383 & 0.337 & -0.445 & 0.601 & 0.772 & -0.383 & 0.270 & -0.096 & 0.66 \\
\hline & $4.64^{* * * *}$ & $-3.88^{* * * *}$ & $2.58^{\text {**** }}$ & $-2.89^{* * * *}$ & $3.35^{\text {**** }}$ & $4.11^{* * * *}$ & $-3.23^{* * *}$ & $2.07 * *$ & -0.54 & $3.64 * * *$ \\
\hline Rank.Vol(PDI $\left.I_{t}\right)$ & 0.300 & -0.274 & 0.105 & 0.157 & 0.550 & 0.429 & -0.250 & 0.110 & 0.033 & 0.334 \\
\hline & $2.17^{* *}$ & $-3.68^{\text {**** }}$ & 1.54 & 1.53 & $4.26^{\text {**** }}$ & $3.11^{* * *}$ & $-3.28^{* * * *}$ & 1.39 & 0.34 & $2.89^{* * *}$ \\
\hline Size $_{t}$ & -0.210 & 0.061 & 0.067 & -0.120 & -0.199 & -0.253 & 0.061 & 0.073 & -0.076 & -0.136 \\
\hline & $-3.70^{* * * *}$ & $2.19^{* *}$ & $3.00^{\text {**** }}$ & $-4.48^{* * * *}$ & $-2.17^{* *}$ & $-5.14^{* * * *}$ & $1.93^{*}$ & $2.75^{* * *}$ & $-2.93^{* * * *}$ & -1.61 \\
\hline Foreign $_{t}$ & -2.817 & -2.070 & 1.522 & 0.586 & -0.996 & -2.220 & -2.258 & 1.583 & 0.746 & -1.259 \\
\hline & $-2.72^{* * * *}$ & $-6.45^{* * * *}$ & $3.86^{\text {**** }}$ & 0.94 & -0.69 & $-1.72^{*}$ & $-5.53^{* * * *}$ & $3.36^{* * *}$ & $1.91^{*}$ & -0.96 \\
\hline Financial $_{t}$ & -0.810 & 0.163 & -0.309 & 0.473 & -0.310 & -0.453 & 0.357 & -0.418 & 0.229 & -0.235 \\
\hline & -1.30 & 0.72 & -1.47 & $1.69^{*}$ & -0.83 & -0.79 & 1.60 & -1.61 & 0.73 & -1.06 \\
\hline$D \_i n c_{t}$ & -0.094 & -0.001 & 0.332 & -0.504 & -0.155 & -0.199 & 0.036 & 0.102 & -0.133 & -0.232 \\
\hline & -1.06 & -0.03 & $8.16^{\text {**** }}$ & $-7.76^{\text {**** }}$ & -1.31 & $-1.77^{*}$ & 0.86 & $1.77^{*}$ & $-2.47^{* *}$ & -1.98 ** \\
\hline$R E / B V E_{t}$ & -1.583 & 0.346 & 0.361 & -0.277 & -1.486 & -1.426 & 0.348 & 0.259 & -0.113 & -0.723 \\
\hline & $-5.20^{* * * *}$ & $2.24^{* *}$ & $2.39^{* *}$ & $-1.81^{*}$ & & $-5.87^{* * *}$ & $1.97^{* *}$ & $2.21^{* *}$ & -0.93 & $-4.53^{* * *}$ \\
\hline D_Nothing ${ }_{t-1}$ & 2.768 & & -0.389 & & & 1.932 & -1.701 & -0.321 & -1.642 & -1.207 \\
\hline & $10.73^{\text {**** }}$ & & -1.63 & & & $8.24^{* * * *}$ & $-5.02^{* * *}$ & -1.56 & $-6.76^{* * * *}$ & $-5.88^{* * *}$ \\
\hline$D_{\text {Stable }}{ }_{t-1}$ & & 1.046 & -0.665 & 0.064 & 0.250 & -1.669 & 0.653 & -0.419 & 0.181 & 0.389 \\
\hline & & $12.76^{\text {**** }}$ & $-4.94^{* * * *}$ & 0.63 & $1.91^{*}$ & $-11.78^{* * *}$ & $9.79^{* * * *}$ & $-5.07^{* * *}$ & $2.31^{* *}$ & $2.26^{\text {*** }}$ \\
\hline$D_{-}$Increase $_{t-1}$ & & -0.118 & -0.039 & 1.370 & 0.232 & -1.693 & 0.221 & -0.001 & 0.313 & 0.523 \\
\hline & & -1.11 & -0.32 & $7.35^{\text {***** }}$ & 0.87 & $-6.74^{* * * *}$ & $2.69^{* * * *}$ & -0.01 & $2.78^{* * * *}$ & 2.22 *** \\
\hline Year dummy & Yes & Yes & Yes & Yes & Yes & Yes & Yes & Yes & Yes & Yes \\
\hline Pseudo $\mathrm{R}^{2}$ & 0.440 & 0.083 & U & 7 & & & & 0.105 & & \\
\hline$N$ & 3,919 & 14,004 & 15,890 & 14,004 & 14,004 & 15,890 & 15,890 & 15,890 & 15,890 & 15,890 \\
\hline
\end{tabular}

Nothing means a firm-year without any dividend for both Fiscal Year $t(t+1)$ and Fiscal Year $t+1(t+2)$.

Stable means a firm-year paying as much DPS for Fiscal Year $\mathrm{t}+1(\mathrm{t}+2)$ as Fiscal Year $\mathrm{t}(\mathrm{t}+1)$.

Increase means a firm-year paying more DPS for Fiscal Year $\mathrm{t}+1(\mathrm{t}+2)$ than DPS for Fiscal Year $\mathrm{t}(\mathrm{t}+1)$.

Decrease means a firm-year paying less DPS for Fiscal year $t+1(t+2)$ than Fiscal Year $t(t+1)$.

Omission means a firm-year omitting dividends for Fiscal year $\mathrm{t}+1(\mathrm{t}+2)$.

D_Nothing ${ }_{t}=1$ if a firm-year's dividend policy from $\mathrm{t}(\mathrm{t}+1)$ to $\mathrm{t}+1(\mathrm{t}+2)$ is Nothing, and 0 otherwise.

D_Stable $t_{t}=1$ if a firm-year's dividend policy from $\mathrm{t}(\mathrm{t}+1)$ to $\mathrm{t}+1(\mathrm{t}+2)$ is Stable, and 0 otherwise.

$D_{\text {Increase }},=1$ if a firm-year's dividend policy from $\mathrm{t}(\mathrm{t}+1)$ to $\mathrm{t}+1(\mathrm{t}+2)$ is Increase, and 0 otherwise.

D_Decrease $t_{t}=1$ if a firm-year's dividend policy from $\mathrm{t}(\mathrm{t}+1)$ to $\mathrm{t}+1(\mathrm{t}+2)$ is Decrease, and 0 otherwise.

D_Omission $t_{t}=1$ if a firm-year's dividend policy from $\mathrm{t}(\mathrm{t}+1)$ to $\mathrm{t}+1(\mathrm{t}+2)$ is Omission, and 0 otherwise.

$N I_{t}=$ the net income for Fiscal Year $\mathrm{t}$, deflated by the total assets at the beginning of Fiscal Year $\mathrm{t}$.

$\operatorname{Vol}(N I)_{t}=$ the firm-specific volatility of earnings that is calculated as the standard deviation of NI over the most recent five years.

$T A C_{t}=$ total accrual that is defined as (change in current assets - change in cash and cash equivalents) (change in liabilities - change in financing

item) - change in other allowance - depreciation for Fiscal Year t, deflated by the total assets at the beginning of Fiscal Year $\mathrm{t}$.

$N D A C_{t}=$ non discretionary accrual that is estimated by using Kothari et al. (2005) 's model.

$D A C_{t}=$ discretionary accrual that is definded by $T A C_{t}$ minus $N D A C_{t}$. 
(-Continued)



All z-statistics are corrected for heteroskedasticity, and cross-sectional and time-series correlation using a two-way cluster at the firm and year level proposed by Petersen (2009) and Cameron et al. (2011).

******, and * indicate significance at $1 \%, 5 \%$, and $10 \%$, respectively.

\section{Robustness Check}

In this paper, the degree of smoothing is defined as firm-specific historical volatility of net income, divided by volatility of pre-discretionary income $\left(\operatorname{Vol}(N I) / \operatorname{Vol}(P D I)_{t}\right)$. In addition, to control for industry and time effects, following Tucker and Zarowin (2006), this study uses a firm's reversed fractional ranking of income smoothing (between 0 and 1) within its industry-year and refers to it as Income Smoothing $(I S)$. Our IS measure includes both accrual discretion and real discretion.

It may be possible that this measure includes bias. For the purpose of robustness check, we adopts three additional $I S$ measures. The second measure (IS2) is defined as the ratio of the firm's standard deviation of $N I$ over the most recent five years to its standard deviation of net income before accrual discretion ( $N I$ minus $D A C$, hereafter NIBAD) over the most recent five years: Vol(NI)/ $\operatorname{Vol}(N I B A D)$. Although IS2 is used by Hunt et al. (2000), IS2 does not include real discretion portion.

Our Second Income Smoothing Measure = Vol(NI) / Vol(NIBAD)

$I S 2=$ the within industry-year reversed fractional ranking (between 0 and 1) of $\operatorname{Vol}(N I) / \operatorname{Vol}(N I B A D)$ for Fiscal Year $\mathrm{t}$ 
Table 10: Results for The Earnings Persistence Regression in Model (2)

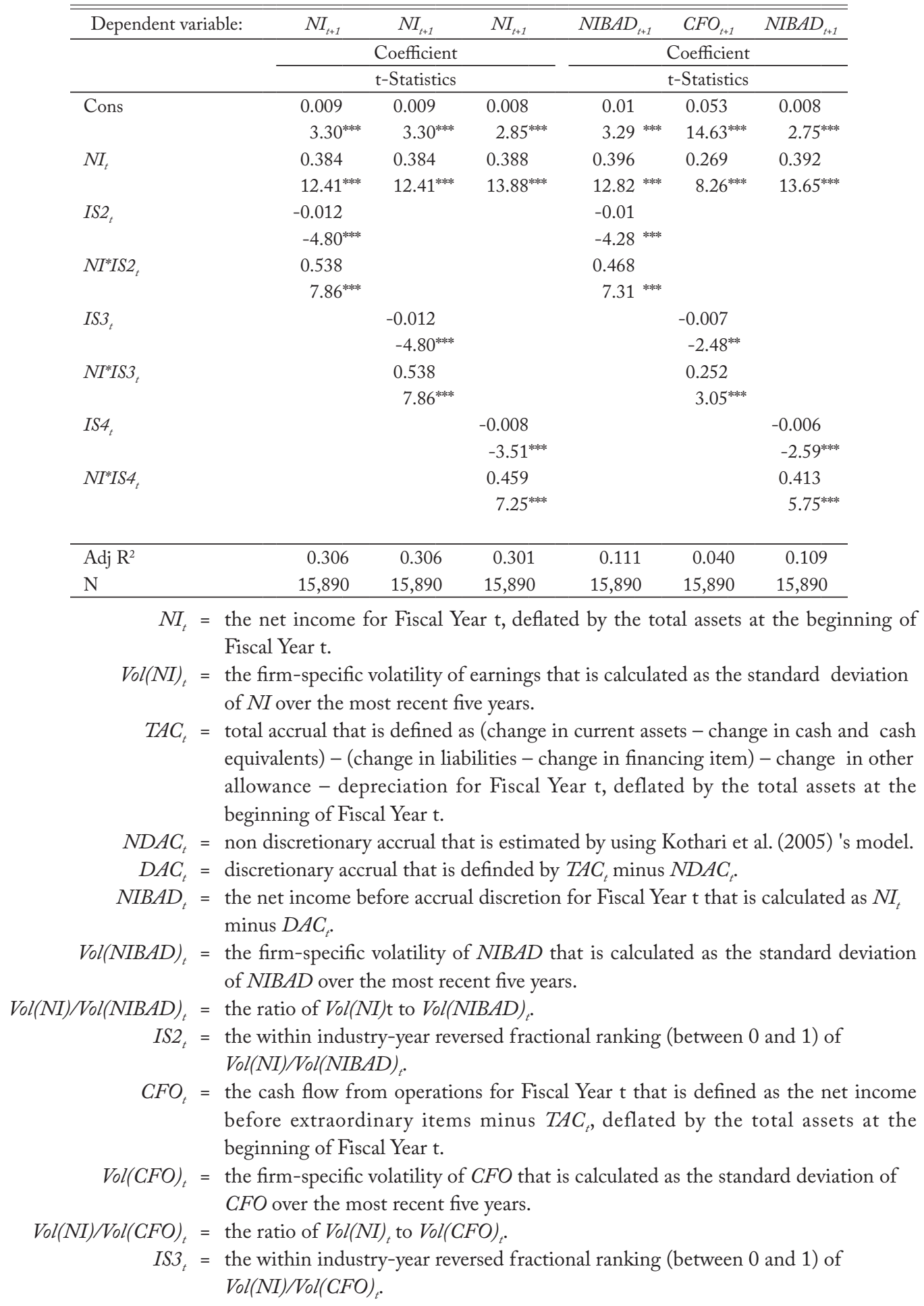




\section{(-Continued)}

$$
\begin{aligned}
& \rho(\triangle D A C, \triangle N I B A D)_{t}=\text { the correlation coefficient between change in } D A C \text { and change in NIBAD over } \\
& \text { the most recent five years. } \\
& I S 4_{t}=\text { the within industry-year reversed fractional ranking (between } 0 \text { and } 1 \text { ) of } \\
& \rho(\triangle D A C, \triangle N I B A D)_{t} \text {. }
\end{aligned}
$$

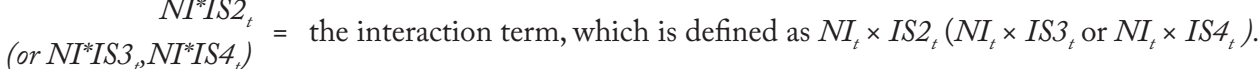

\footnotetext{
All t-statistics are corrected for heteroskedasticity, and cross-sectional and time-series correlation using a two-way cluster at the firm and year level proposed by Petersen (2009).

$* * * * *$, and $*$ indicate significance at $1 \%, 5 \%$ and $10 \%$, respectively.
}

Our third measure (IS3) is defined as the ratio of the firm's standard deviation of $N I$ over the most recent five years to its standard deviation of CFO over the most recent five years: Vol(NI)/ $\operatorname{Vol}(C F O)$. This measure is widely used in prior studies (Leuz et al. 2003; Francis et al. 2004). In this paper, $C F O$ is defined as the net income before extraordinary items minus $T A C$.

$$
\begin{gathered}
\text { Our Third Income Smoothing Measure }=\operatorname{Vol}(N I) / \operatorname{Vol}(C F O) \\
I S 3=\text { the within industry-year reversed fractional ranking (between } 0 \text { and } 1) \text { of } \\
\operatorname{Vol}(N I) / \operatorname{Vol}(C F O) \text { for Fiscal Year t }
\end{gathered}
$$

The fourth measure (IS4) follows Tucker and Zarowin (2006)'s idea. We redefined "smoothing" as a correlation coefficient between change in $D A C$ and change in NIBAD over the most recent five years.

Our Forth Income Smoothing Measure $=\rho(\triangle D A C, \triangle N I B A D)$

$I S 4=$ the within industry-year reversed fractional ranking (between 0 and 1 ) of $\rho(\triangle D A C, \triangle N I B A D)$, for Fiscal Year $\mathrm{t}$

To maintain consistency with our primary tests, these three alternative proxies for income smoothing are also converted into the within industry-year reversed fractional ranking (between 0 and 1), respectively, to control for industry and time effects.

These three alternative definitions for $I S$ are substituted for all analyses in this paper, including those presented in Tables 4-9. In total, with regard to IS's definitions, we conduct eighteen robustness check analyses. Still the tenor of the results remains unchanged. In that sense, there are good grounds to consider this study's evidence robust, irrespective of the alternative income smoothing measures. The main robustness check results of Table 5, 6 (persistence) and Table 9 (dividend policy) are shown in Table 10 and Table 11, respectively.

In addition, we use industry-years' median values to standardize some proxies (i.e. Vol(NI)/ $\operatorname{Vol}(P D I), R O A$, Growth, $\operatorname{Vol}(P D I))$ instead of the firms' fractional rankings within their industryyear. In particular, these alternative standardized variables are defined as the differences between raw variables and each industry-year median, deflated by the absolute value of the industry-year median. Even in this case, the empirical results remain also unchanged (untabulated). 
Table 11: Tests of Relation Between Income Smoothing and Dividend Policy

\begin{tabular}{|c|c|c|c|c|c|c|c|c|c|c|}
\hline \multicolumn{11}{|c|}{ Panel A: Using IS2 } \\
\hline & \multicolumn{5}{|c|}{ Dividend policy from $t$ to $t+1$} & \multicolumn{5}{|c|}{ Dividend policy from $t+1$ to $t+2$} \\
\hline & \multicolumn{5}{|c|}{$\begin{array}{c}\text { Coefficient } \\
\text { z-value }\end{array}$} & \multicolumn{5}{|c|}{$\begin{array}{l}\text { Coefficient } \\
\text { z-value }\end{array}$} \\
\hline & D_Notbing & D_Stable & D_Increase & D_Decrease & D_Omission & D_Notbing & D_Stable & D_Increase & D_Decrease & D_Omission \\
\hline \multirow[t]{2}{*}{ Cons } & 1.374 & -0.452 & -2.948 & 0.349 & -0.401 & 1.899 & -0.718 & -2.375 & -1.055 & -2.052 \\
\hline & $2.07^{* *}$ & -1.54 & $-15.06^{* * * *}$ & 1.26 & -0.51 & $4.53^{* * * *}$ & $-2.15^{* *}$ & $-8.95^{* * *}$ & $-3.56^{* * * *}$ & $-2.60^{* * * *}$ \\
\hline \multirow{2}{*}{$I S 2_{t}$} & -0.654 & 0.322 & -0.159 & -0.064 & -0.540 & -0.623 & 0.271 & -0.086 & -0.025 & -0.360 \\
\hline & $-2.56^{* *}$ & $4.08^{* * *}$ & $-1.76^{*}$ & -0.72 & $-2.99^{* * * *}$ & $-2.86^{* * * *}$ & $3.79^{* * *}$ & -0.85 & -0.34 & $-2.24^{* *}$ \\
\hline \multirow[t]{2}{*}{ Rank.ROA $A_{t}$} & -1.910 & -0.007 & 1.104 & -1.220 & -2.816 & -2.202 & 0.257 & 0.498 & -0.174 & -2.022 \\
\hline & $-8.04^{* * * *}$ & -0.04 & $14.11^{\text {**** }}$ & $-7.52^{* * *}$ & $-11.16^{* * *}$ & $-7.76^{* * * *}$ & $1.95^{*}$ & $5.19^{* * * *}$ & -0.95 & $-10.36^{* * * *}$ \\
\hline \multirow{2}{*}{ Rank.Growth } & -0.199 & -0.037 & 0.231 & -0.209 & -0.018 & -0.034 & -0.087 & 0.165 & -0.035 & 0.165 \\
\hline & -1.24 & -0.40 & $2.57^{* *}$ & $-2.13^{* *}$ & -0.12 & -0.24 & -1.43 & $2.18^{* *}$ & -0.43 & 1.16 \\
\hline \multirow[t]{2}{*}{ Tobin's $Q_{t}$} & 1.059 & -0.389 & 0.339 & -0.437 & 0.620 & 0.787 & -0.392 & 0.274 & -0.092 & 0.674 \\
\hline & $5.00^{* * * *}$ & $-3.94^{* * *}$ & $2.61^{* * * *}$ & $-2.80^{* * * *}$ & $3.48^{* * * *}$ & $4.18^{* * *}$ & $-3.30^{* * * *}$ & $2.13^{* *}$ & -0.51 & $3.68^{* * * *}$ \\
\hline \multirow[t]{2}{*}{ Rank.Vol(NIBAD) } & 0.223 & -0.218 & 0.086 & 0.114 & 0.418 & 0.351 & -0.185 & 0.080 & 0.015 & 0.268 \\
\hline & $1.86^{*}$ & $-3.49^{* * * *}$ & 1.41 & 1.33 & $4.48^{* * * *}$ & $2.92^{* * * *}$ & $-2.91^{* * *}$ & 1.13 & 0.16 & $2.29^{* *}$ \\
\hline \multirow{2}{*}{ Size $_{t}$} & -0.210 & 0.063 & 0.067 & -0.123 & -0.206 & -0.255 & 0.064 & 0.072 & -0.077 & -0.140 \\
\hline & $-3.79^{* * *}$ & $2.26^{* *}$ & $2.96^{\text {**** }}$ & $-4.67^{* * *}$ & $-2.29^{* *}$ & $-5.18^{* * * *}$ & $2.01^{* *}$ & $2.71^{* * * *}$ & $-3.02^{* * * *}$ & $-1.69^{*}$ \\
\hline \multirow[t]{2}{*}{ Foreign $_{t}$} & -2.855 & -2.081 & 1.525 & 0.607 & -0.930 & -2.226 & -2.276 & 1.592 & 0.758 & -1.235 \\
\hline & $-2.72^{* * * *}$ & $-6.52^{* * * *}$ & $3.89^{* * * *}$ & 0.99 & -0.64 & $-1.71^{*}$ & $-5.59^{* * *}$ & $3.40^{* * * *}$ & $1.95^{*}$ & -0.95 \\
\hline \multirow[t]{2}{*}{ Financial $_{t}$} & -0.832 & 0.166 & -0.312 & 0.472 & -0.312 & -0.480 & 0.360 & -0.420 & 0.230 & -0.237 \\
\hline & -1.37 & 0.74 & -1.49 & $1.69^{*}$ & -0.81 & -0.84 & 1.60 & -1.62 & 0.73 & -1.06 \\
\hline \multirow[t]{2}{*}{$D_{-i n c_{t}}$} & -0.106 & 0.002 & 0.331 & -0.506 & -0.158 & -0.203 & 0.039 & 0.100 & -0.135 & -0.236 \\
\hline & -1.18 & 0.04 & $8.22^{* * * *}$ & $-7.82^{* * *}$ & -1.33 & $-1.82^{*}$ & 0.95 & $1.74^{*}$ & $-2.49 * *$ & $-1.99^{* *}$ \\
\hline \multirow[t]{2}{*}{$R E / B V E_{t}$} & -1.593 & 0.356 & 0.359 & -0.288 & -1.514 & -1.436 & 0.362 & 0.253 & -0.121 & -0.735 \\
\hline & $-5.08^{* * * *}$ & $2.29^{* *}$ & $2.38^{* * *}$ & $-1.94^{*}$ & $-5.77^{* * *}$ & $-5.84^{* * * *}$ & $2.02^{* *}$ & $2.17^{* *}$ & -1.02 & $-4.69^{* * * *}$ \\
\hline \multirow{2}{*}{ D_Nothing $g_{t-1}$} & 2.768 & & -0.390 & & & 1.929 & -1.705 & -0.319 & -1.638 & -1.202 \\
\hline & $10.67^{\text {**** }}$ & & -1.63 & & & $8.28^{* * * *}$ & $-5.02^{* * *}$ & -1.56 & $-6.74^{* * *}$ & $-5.77^{* * * *}$ \\
\hline \multirow[t]{2}{*}{$D_{\text {Stable }}$ t-1 $_{1}$} & & 1.05 & -0.667 & 0.058 & 0.232 & -1.676 & 0.660 & -0.422 & 0.176 & 0.376 \\
\hline & & $12.72^{* * * *}$ & $-4.90^{* * * *}$ & 0.56 & $1.84^{*}$ & $-11.89^{* * * *}$ & $9.94^{* * * *}$ & $-5.08^{* * * *}$ & $2.22^{* *}$ & $2.15^{* *}$ \\
\hline \multirow[t]{2}{*}{$D_{\text {_Increase }}$ t-1 } & & -0.115 & -0.040 & 1.367 & 0.225 & -1.698 & 0.225 & -0.003 & 0.310 & 0.515 \\
\hline & & -1.08 & -0.33 & $7.36^{* * * *}$ & 0.85 & $-6.74^{* * *}$ & $2.73^{* * *}$ & -0.02 & $2.75^{* * * *}$ & $2.18^{* *}$ \\
\hline Year dummy & Yes & Yes & Yes & Yes & Yes & Yes & Yes & Yes & Yes & Yes \\
\hline Pseudo $\mathrm{R}^{2}$ & 0.440 & 0.083 & 0.139 & 0.147 & 0.166 & 0.509 & 0.089 & 0.105 & 0.112 & 0.101 \\
\hline $\mathrm{N}$ & 3,919 & 14,004 & 15,890 & 14,004 & 14,004 & 15,890 & 15,890 & 15,890 & 15,890 & 15,890 \\
\hline
\end{tabular}

Nothing means a firm-year without any dividend for both Fiscal Year $t(t+1)$ and Fiscal Year $t+1(t+2)$.

Stable means a firm-year paying as much DPS for Fiscal Year $\mathrm{t}+1(\mathrm{t}+2)$ as Fiscal Year $\mathrm{t}(\mathrm{t}+1)$.

Increase means a firm-year paying more DPS for Fiscal Year $\mathrm{t}+1(\mathrm{t}+2)$ than DPS for Fiscal Year $\mathrm{t}(\mathrm{t}+1)$.

Decrease means a firm-year paying less DPS for Fiscal year $t+1(t+2)$ than Fiscal Year $t(t+1)$.

Omission means a firm-year omitting dividends for Fiscal year $\mathrm{t}+1(\mathrm{t}+2)$.

D_Nothing _ $_{t}=1$ if a firm-year's dividend policy from $\mathrm{t}(\mathrm{t}+1)$ to $\mathrm{t}+1(\mathrm{t}+2)$ is Nothing, and 0 otherwise.

$D_{-}$Stable $_{t}=1$ if a firm-year's dividend policy from $\mathrm{t}(\mathrm{t}+1)$ to $\mathrm{t}+1(\mathrm{t}+2)$ is Stable, and 0 otherwise.

D_Increase $_{t}=1$ if a firm-year's dividend policy from $\mathrm{t}(\mathrm{t}+1)$ to $\mathrm{t}+1(\mathrm{t}+2)$ is Increase, and 0 otherwise.

D_Decrease $t_{t}=1$ if a firm-year's dividend policy from $\mathrm{t}(\mathrm{t}+1)$ to $\mathrm{t}+1(\mathrm{t}+2)$ is Decrease, and 0 otherwise.

D_Omission $t_{t}=1$ if a firm-year's dividend policy from $\mathrm{t}(\mathrm{t}+1)$ to $\mathrm{t}+1(\mathrm{t}+2)$ is Omission, and 0 otherwise.

$N I_{t}=$ the net income for Fiscal Year $\mathrm{t}$, deflated by the total assets at the beginning of Fiscal Year $\mathrm{t}$.

$\operatorname{Vol}(N I)_{t}=$ the firm-specific volatility of earnings that is calculated as the standard deviation of $N I$ over the most recent five years.

$T A C_{t}=$ total accrual that is defined as (change in current assets - change in cash and cash equivalents) - (change in liabilities - change in financing item) - change in other allowance

- depreciation for Fiscal Year $\mathrm{t}$, deflated by the total assets at the beginning of Fiscal Year $\mathrm{t}$.

$N D A C_{t}=$ non discretionary accrual that is estimated by using Kothari et al. (2005) 's model. 


\section{(-Continued)}

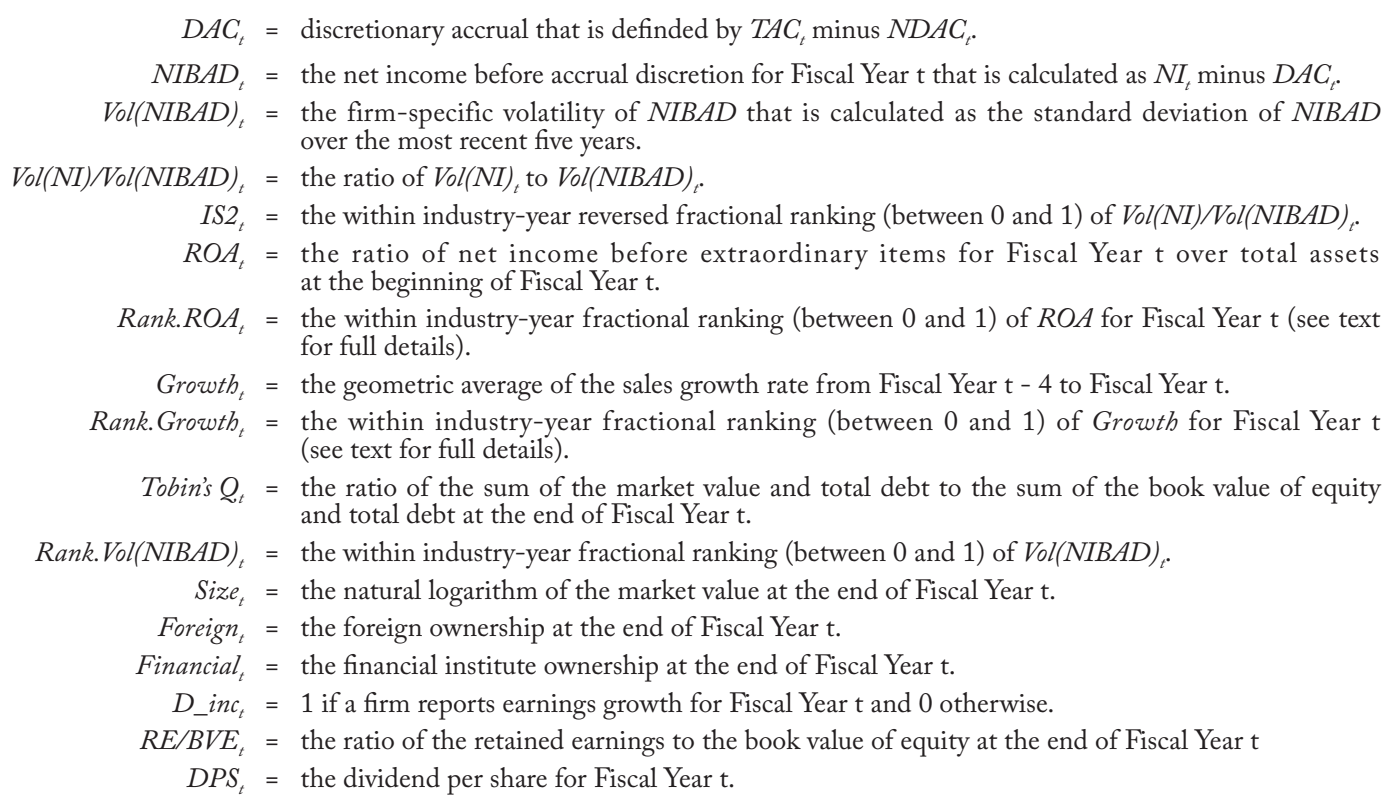

All z-statistics are corrected for heteroskedasticity, and cross-sectional and time-series correlation using a two-way cluster at the firm and year level proposed by Petersen (2009) and Cameron et al. (2011).

*****, and * indicate significance at $1 \%, 5 \%$, and $10 \%$, respectively.

Panel B: Using IS3

\begin{tabular}{|c|c|c|c|c|c|c|c|c|c|c|}
\hline & \multicolumn{5}{|c|}{ Dividend policy from $t$ to $t+1$} & \multicolumn{5}{|c|}{ Dividend policy from $t+1$ to $t+2$} \\
\hline & \multicolumn{5}{|c|}{$\begin{array}{l}\text { Coefficient } \\
\text { z-value }\end{array}$} & \multicolumn{5}{|c|}{$\begin{array}{c}\text { Coefficient } \\
\mathrm{z} \text {-value }\end{array}$} \\
\hline & D_Notbing & D_Stable & D_Increase & D_Decrease & D_Omission & D_Nothing & D_Stable & D_Increase & D_Decrease & D_Omission \\
\hline \multirow[t]{2}{*}{ Cons } & 1.347 & -0.433 & -2.964 & 0.304 & -0.497 & 1.867 & -0.699 & -2.388 & -1.062 & -2.055 \\
\hline & $1.92 *$ & -1.46 & $-15.30^{* * * *}$ & 1.14 & -0.64 & $4.63^{* * * *}$ & $-2.22 * *$ & $-9.84^{* * *}$ & $-3.67^{* * * *}$ & $-2.43^{* *}$ \\
\hline \multirow[t]{2}{*}{$I S 3_{t}$} & -0.749 & 0.399 & -0.201 & -0.125 & -0.699 & -0.741 & 0.339 & -0.121 & -0.034 & -0.433 \\
\hline & $-2.80^{* * * * *}$ & $4.71^{* * * *}$ & $-1.89^{*}$ & -1.15 & $-3.28^{* * * *}$ & $-3.33^{* * *}$ & 3.73 *** & -0.94 & -0.46 & $-2.61^{* * * *}$ \\
\hline \multirow[t]{2}{*}{ Rank.ROA } & -1.910 & 0.002 & 1.100 & -1.228 & -2.830 & -2.202 & 0.264 & 0.495 & -0.176 & -2.028 \\
\hline & $-8.05^{* * * *}$ & 0.01 & $13.87^{\text {**** }}$ & $-7.55^{\text {**** }}$ & $-11.71^{* * * *}$ & $-7.89^{* * * *}$ & $2.00 * *$ & $5.08^{* * * *}$ & -0.96 & $-10.47^{\text {**** }}$ \\
\hline \multirow[t]{2}{*}{ Rank.Growth } & -0.195 & -0.044 & 0.234 & -0.203 & 0.012 & -0.019 & -0.093 & 0.167 & -0.034 & 0.176 \\
\hline & -1.22 & -0.48 & $2.60^{\text {**** }}$ & $-2.05^{\text {*** }}$ & 0.08 & -0.13 & -1.54 & $2.23^{* *}$ & -0.42 & 1.22 \\
\hline \multirow[t]{2}{*}{ Tobin's $Q_{t}$} & 1.059 & -0.382 & 0.334 & -0.448 & 0.596 & 0.777 & -0.386 & 0.270 & -0.094 & 0.667 \\
\hline & $4.67^{* * * *}$ & $-3.85^{* * * *}$ & $2.54^{* *}$ & $-2.86^{* * *}$ & $3.33^{* * * *}$ & $4.09^{* * * *}$ & $-3.27^{* * *}$ & $2.08^{* *}$ & -0.53 & $8^{* * * * *}$ \\
\hline \multirow[t]{2}{*}{ Rank.Vol $\left(C F O_{t}\right)$} & 0.294 & -0.299 & 0.138 & 0.205 & 0.624 & 0.440 & -0.258 & 0.122 & 0.030 & 0.321 \\
\hline & $2.22^{* *}$ & $-4.02^{* * *}$ & 1.50 & $1.86^{*}$ & $3.76^{\text {**** }}$ & $3.71^{* * *}$ & $-2.91 * * *$ & 1.25 & 0.39 & $2.31^{* *}$ \\
\hline \multirow[t]{2}{*}{$S_{i z e_{t}}$} & -0.207 & 0.061 & 0.068 & -0.120 & -0.199 & -0.251 & 0.062 & 0.073 & -0.077 & -0.139 \\
\hline & & $2.19^{* *}$ & $2.97^{* * * *}$ & $-4.47^{* * * *}$ & $-2.21^{* *}$ & $-5.19^{* * *}$ & $2.01 * *$ & $2.75^{\text {**** }}$ & $-3.03^{* * * *}$ & -1.61 \\
\hline \multirow[t]{2}{*}{ Foreign $_{t}$} & -2.908 & -2.071 & 1.518 & 0.584 & -1.007 & -2.284 & -2.266 & 1.586 & 0.755 & -1.240 \\
\hline & $-2.82^{* * * *}$ & $-6.37^{* * * *}$ & $3.81^{* * * *}$ & 0.93 & -0.71 & $-1.80^{*}$ & -5.55 **** & $3.34^{* * * *}$ & $1.94^{*}$ & -0.94 \\
\hline \multirow[t]{2}{*}{ Financial $_{t}$} & -0.836 & 0.162 & -0.307 & 0.479 & -0.306 & -0.466 & 0.355 & -0.417 & 0.232 & -0.233 \\
\hline & -1.39 & 0.71 & -1.46 & $1.74^{*}$ & -0.82 & -0.83 & 1.58 & -1.62 & 0.74 & -1.06 \\
\hline \multirow[t]{2}{*}{$D \_i n c_{t}$} & -0.096 & -0.002 & 0.333 & -0.503 & -0.154 & -0.200 & 0.036 & 0.102 & -0.134 & -0.233 \\
\hline & -1.09 & -0.06 & $8.08^{\text {**** }}$ & $-7.81^{\text {**** }}$ & -1.31 & $-1.79^{*}$ & 0.88 & $1.76^{*}$ & $-2.49^{* *}$ & $-1.98^{* *}$ \\
\hline \multirow[t]{2}{*}{$R E / B V E_{t}$} & -1.581 & 0.342 & 0.365 & -0.277 & -1.491 & -1.424 & 0.352 & 0.258 & -0.120 & -0.732 \\
\hline & $-5.17^{* * * *}$ & $2.23^{* *}$ & $2.40^{* *}$ & $-1.83^{*}$ & $-5.97^{*}$ & $-5.87^{* * * *}$ & $1.99 * *$ & $2.23^{* *}$ & -1.00 & $-4.60^{* * * *}$ \\
\hline \multirow[t]{2}{*}{ D_Nothing ${ }_{t-1}$} & 2.765 & & -0.391 & & & 1.930 & -1.704 & -0.319 & -1.638 & -1.201 \\
\hline & $10.72^{* * * *}$ & & -1.64 & & & $8.30^{* * * *}$ & $-5.02 * * *$ & -1.56 & $-6.73^{* * * *}$ & $-5.89^{* * * *}$ \\
\hline
\end{tabular}

(Continued) 


\section{(-Continued)}

\begin{tabular}{|c|c|c|c|c|c|c|c|c|c|c|}
\hline D_Stable $t_{t-1}$ & & $\begin{array}{l}1.044 \\
12.63^{\text {**** }}\end{array}$ & $\begin{array}{l}-0.663 \\
-4.91^{\text {冰* }}\end{array}$ & $\begin{array}{r}0.064 \\
0.63\end{array}$ & $\begin{array}{c}0.246 \\
1.88^{*}\end{array}$ & $\begin{array}{l}-1.667 \\
-11.71^{* * *}\end{array}$ & $\begin{array}{l}0.655 \\
9.80^{* * *}\end{array}$ & $\begin{array}{l}-0.419 \\
-5.04^{\text {*** }}\end{array}$ & $\begin{array}{l}0.177 \\
2.22^{* *}\end{array}$ & $\begin{array}{l}0.382 \\
2.24^{\text {*** }}\end{array}$ \\
\hline$D_{-}$Increase $_{t-1}$ & & $\begin{array}{r}-0.118 \\
-1.11\end{array}$ & $\begin{array}{r}-0.039 \\
-0.32\end{array}$ & $\begin{array}{l}1.371 \\
7.36^{* * * *}\end{array}$ & $\begin{array}{r}0.233 \\
0.87\end{array}$ & $\begin{array}{l}-1.694 \\
-6.73^{* * *}\end{array}$ & $\begin{array}{l}0.222 \\
2.69^{* * *}\end{array}$ & $\begin{array}{r}-0.002 \\
-0.01\end{array}$ & $\begin{array}{l}0.311 \\
2.76^{* * * *}\end{array}$ & $\begin{array}{l}0.521 \\
2.23^{* * *}\end{array}$ \\
\hline Year dummy & Yes & Yes & Yes & Yes & Yes & Yes & Yes & Yes & Yes & Yes \\
\hline Pseudo $\mathrm{R}^{2}$ & 0.441 & 0.084 & 0.139 & 0.148 & 0.167 & 0.509 & 0.090 & 0.105 & 0.112 & 0.102 \\
\hline $\mathrm{N}$ & 3,919 & 14,004 & 15,890 & 14,004 & 14,004 & 15,890 & 15,890 & 15,890 & 15,890 & 15,890 \\
\hline
\end{tabular}

Nothing means a firm-year without any dividend for both Fiscal Year $t(t+1)$ and Fiscal Year $t+1(t+2)$.

Stable means a firm-year paying as much DPS for Fiscal Year $\mathrm{t}+1(\mathrm{t}+2)$ as Fiscal Year $\mathrm{t}(\mathrm{t}+1)$.

Increase means a firm-year paying more DPS for Fiscal Year $\mathrm{t}+1(\mathrm{t}+2)$ than DPS for Fiscal Year $\mathrm{t}(\mathrm{t}+1)$.

Decrease means a firm-year paying less DPS for Fiscal year $\mathrm{t}+1(\mathrm{t}+2)$ than Fiscal Year $\mathrm{t}(\mathrm{t}+1)$.

Omission means a firm-year omitting dividends for Fiscal year $t+1(t+2)$.

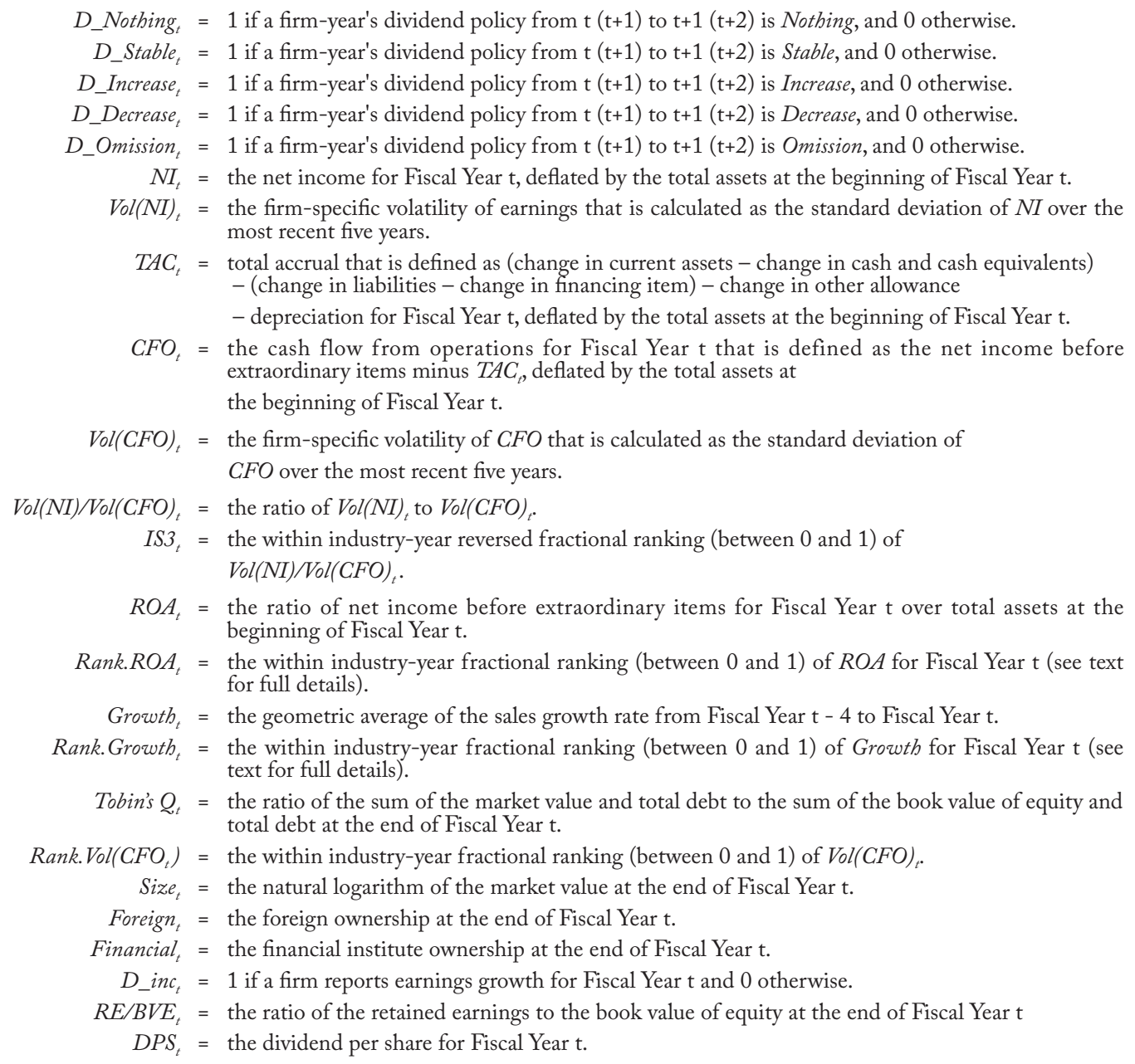




\section{(-Continued)}

All z-statistics are corrected for heteroskedasticity, and cross-sectional and time-series correlation using a two-way cluster at the firm and year level proposed by Petersen (2009) and Cameron et al. (2011). *******, and * indicate significance at $1 \%, 5 \%$, and $10 \%$, respectively.

Panel C: Using IS4

\begin{tabular}{|c|c|c|c|c|c|c|c|c|c|c|}
\hline & \multicolumn{5}{|c|}{ Dividend policy from $t$ to $t+1$} & \multicolumn{5}{|c|}{ Dividend policy from $t+1$ to $t+2$} \\
\hline & \multicolumn{5}{|c|}{$\begin{array}{c}\text { Coefficient } \\
\text { z-value }\end{array}$} & \multicolumn{5}{|c|}{$\begin{array}{c}\text { Coefficient } \\
\text { z-value }\end{array}$} \\
\hline & D_Notbing & D_Stable & D_Increase & D_Decrease & D_Omission & D_Nothing & D_Stable & D_Increase & D_Decrease & D_Omission \\
\hline \multirow[t]{2}{*}{ Cons } & 1.373 & -0.419 & -2.966 & 0.348 & -0.390 & 1.887 & -0.691 & -2.380 & -1.065 & -2.042 \\
\hline & $2.03^{* *}$ & -1.41 & $-15.03^{* * * *}$ & 1.23 & -0.500 & $4.47^{* * *}$ & $-2.04^{* *}$ & $-8.86^{* * * *}$ & $-3.58^{* * * *}$ & $-2.63^{* * *}$ \\
\hline \multirow[t]{2}{*}{$I S 4_{t}$} & -0.567 & 0.254 & -0.133 & -0.074 & -0.711 & -0.538 & 0.204 & -0.093 & 0.028 & -0.477 \\
\hline & $-2.07^{* *}$ & $3.72^{* * * *}$ & -1.17 & -0.74 & $-3.19^{* * *}$ & $-2.81^{* * * *}$ & $2.53^{* *}$ & -0.87 & 0.27 & $-2.62^{* * * *}$ \\
\hline \multirow{2}{*}{ Rank.ROA $A_{t}$} & -1.935 & -0.013 & 1.108 & -1.219 & -2.815 & -2.219 & 0.252 & 0.499 & -0.174 & -2.01 \\
\hline & $-8.06^{* * * *}$ & -0.07 & $14.15^{* * * *}$ & $-7.49^{* * * *}$ & $-11.82^{* * *}$ & $-7.82^{* * *}$ & $1.92^{*}$ & $5.25^{* * *}$ & -0.96 & $-10.34^{* * * *}$ \\
\hline \multirow[t]{2}{*}{ Rank.Vol(NIBAD $)_{t}$} & 0.240 & -0.212 & 0.087 & 0.120 & 0.493 & 0.361 & -0.177 & 0.087 & 0.001 & 0.313 \\
\hline & $2.09^{* *}$ & $-3.36^{* * * *}$ & 1.41 & 1.53 & $4.79^{\text {**** }}$ & $3.11^{* * * *}$ & $-2.76^{* * *}$ & 1.19 & 0.01 & $3.00^{\text {**** }}$ \\
\hline \multirow[t]{2}{*}{ Rank.Growth } & -0.223 & -0.037 & 0.231 & -0.209 & -0.026 & -0.048 & -0.087 & 0.164 & -0.033 & 0.158 \\
\hline & -1.39 & -0.40 & $2.56^{\text {** }}$ & $-2.15^{* *}$ & -0.19 & -0.340 & -1.39 & $2.15^{* *}$ & -0.40 & 1.10 \\
\hline \multirow[t]{2}{*}{ Tobin's $Q_{t}$} & 1.060 & -0.395 & 0.342 & -0.437 & 0.600 & 0.782 & -0.397 & 0.274 & -0.089 & 0.664 \\
\hline & $4.64^{* * * *}$ & $-3.92^{* * * *}$ & $2.61^{\text {***** }}$ & $-2.75^{\text {**** }}$ & $3.29^{* * * *}$ & $4.16^{* * *}$ & $-3.34^{* * * *}$ & $2.14^{* *}$ & -0.50 & $3.62^{\text {**** }}$ \\
\hline \multirow[t]{2}{*}{ Size $_{t}$} & -0.211 & 0.064 & 0.067 & -0.123 & -0.198 & -0.255 & 0.064 & 0.072 & -0.078 & -0.135 \\
\hline & $-3.76^{* * * *}$ & $2.28^{* *}$ & $2.88^{* * * *}$ & $-4.70^{* * * *}$ & $-2.20^{* * *}$ & $-5.31^{* * * *}$ & $2.07^{* *}$ & $2.76^{* * *}$ & $-3.11^{* * *}$ & -1.62 \\
\hline \multirow[t]{2}{*}{ Foreign $_{t}$} & -2.796 & -2.103 & 1.534 & 0.608 & -0.981 & -2.153 & -2.298 & 1.594 & 0.768 & -1.234 \\
\hline & $-2.71^{* * * *}$ & $-6.59^{* * * *}$ & $3.87^{* * * *}$ & 1.00 & -0.68 & $-1.69^{*}$ & $-5.66^{* * *}$ & $3.37^{* * *}$ & $1.96^{* *}$ & -0.95 \\
\hline \multirow[t]{2}{*}{ Financial $_{t}$} & -0.832 & 0.159 & -0.305 & 0.473 & -0.328 & -0.469 & 0.351 & -0.416 & 0.230 & -0.238 \\
\hline & -1.36 & 0.71 & -1.45 & $1.70^{*}$ & -0.890 & -0.82 & 1.57 & -1.60 & 0.73 & -1.09 \\
\hline \multirow[t]{2}{*}{$D \_i n c_{t}$} & -0.107 & 0.005 & 0.330 & -0.506 & -0.161 & -0.209 & 0.042 & 0.100 & -0.136 & -0.237 \\
\hline & -1.290 & 0.13 & $8.27^{* * * *}$ & $-7.83^{\text {**** }}$ & -1.34 & $-1.91^{*}$ & 1.02 & $1.74^{*}$ & $-2.51^{* *}$ & $-2.00^{* *}$ \\
\hline \multirow[t]{2}{*}{$R E / B V E_{t}$} & -1.579 & 0.358 & 0.359 & -0.284 & -1.468 & -1.429 & 0.365 & 0.256 & -0.129 & -0.713 \\
\hline & $-5.15^{* * * *}$ & $2.32^{* *}$ & $2.37^{* *}$ & $-1.88^{*}$ & $-6.12^{* * *}$ & $-5.76^{* * *}$ & $2.07^{* *}$ & $2.19^{* *}$ & -1.06 & $-4.70^{* * * *}$ \\
\hline \multirow{2}{*}{ D_Nothing ${ }_{t-1}$} & 2.760 & & -0.389 & & & 1.922 & -1.708 & -0.320 & -1.633 & -1.219 \\
\hline & $10.59^{\text {**** }}$ & & -1.62 & & & $8.23^{* * * *}$ & $-5.03^{* * *}$ & -1.54 & $-6.72^{* * * *}$ & $-5.96^{* * * *}$ \\
\hline \multirow{2}{*}{$D_{-}$Stable $_{t-1}$} & & 1.064 & -0.673 & 0.056 & 0.215 & -1.703 & 0.672 & -0.425 & 0.172 & 0.367 \\
\hline & & $12.71^{\text {***** }}$ & $-4.98^{* * * *}$ & 0.54 & $1.70^{*}$ & $-12.51^{* * * *}$ & $9.95^{* * *}$ & $-5.15^{* * * *}$ & $2.16^{* *}$ & $2.14^{* *}$ \\
\hline \multirow[t]{2}{*}{$D_{-}$Increase $_{t-1}$} & & -0.110 & -0.042 & 1.366 & 0.207 & -1.708 & 0.228 & -0.003 & 0.310 & 0.507 \\
\hline & & -1.02 & -0.34 & $7.37^{* * * *}$ & 0.81 & $-6.92^{* * *}$ & $2.76^{* * *}$ & -0.03 & $2.75^{* * * *}$ & $2.17^{* *}$ \\
\hline Year dummy & Yes & Yes & Yes & Yes & Yes & Yes & Yes & Yes & Yes & Yes \\
\hline Pseudo $\mathrm{R}^{2}$ & 0.440 & 0.083 & 0.139 & 0.147 & 0.168 & 0.508 & 0.089 & 0.105 & 0.112 & 0.102 \\
\hline $\mathrm{N}$ & 3,919 & 14,004 & 15,890 & 14,004 & 14,004 & 15,890 & 15,890 & 15,890 & 15,890 & 15,890 \\
\hline
\end{tabular}

Nothing means a firm-year without any dividend for both Fiscal Year $\mathrm{t}(\mathrm{t}+1)$ and Fiscal Year $\mathrm{t}+1(\mathrm{t}+2)$.

Stable means a firm-year paying as much DPS for Fiscal Year $\mathrm{t}+1(\mathrm{t}+2)$ as Fiscal Year $\mathrm{t}(\mathrm{t}+1)$.

Increase means a firm-year paying more DPS for Fiscal Year $\mathrm{t}+1(\mathrm{t}+2)$ than DPS for Fiscal Year $\mathrm{t}(\mathrm{t}+1)$.

Decrease means a firm-year paying less DPS for Fiscal year $\mathrm{t}+1(\mathrm{t}+2)$ than Fiscal Year $\mathrm{t}(\mathrm{t}+1)$.

Omission means a firm-year omitting dividends for Fiscal year $\mathrm{t}+1(\mathrm{t}+2)$.

D_Nothing L $_{t}=1$ if a firm-year's dividend policy from $\mathrm{t}(\mathrm{t}+1)$ to $\mathrm{t}+1(\mathrm{t}+2)$ is Nothing, and 0 otherwise.

$D_{-}$Stable $_{t}=1$ if a firm-year's dividend policy from $\mathrm{t}(\mathrm{t}+1)$ to $\mathrm{t}+1(\mathrm{t}+2)$ is Stable, and 0 otherwise.

$D_{-}$Increase $_{t}=1$ if a firm-year's dividend policy from $\mathrm{t}(\mathrm{t}+1)$ to $\mathrm{t}+1(\mathrm{t}+2)$ is Increase, and 0 otherwise.

$D_{-}$Decrease $_{t}=1$ if a firm-year's dividend policy from $\mathrm{t}(\mathrm{t}+1)$ to $\mathrm{t}+1(\mathrm{t}+2)$ is Decrease, and 0 otherwise.

$D_{-}$Omission $_{t}=1$ if a firm-year's dividend policy from $\mathrm{t}(\mathrm{t}+1)$ to $\mathrm{t}+1(\mathrm{t}+2)$ is Omission, and 0 otherwise.

$N I_{t}=$ the net income for Fiscal Year $\mathrm{t}$, deflated by the total assets at the beginning of Fiscal Year $\mathrm{t}$.

(Continued) 


\section{(-Continued)}

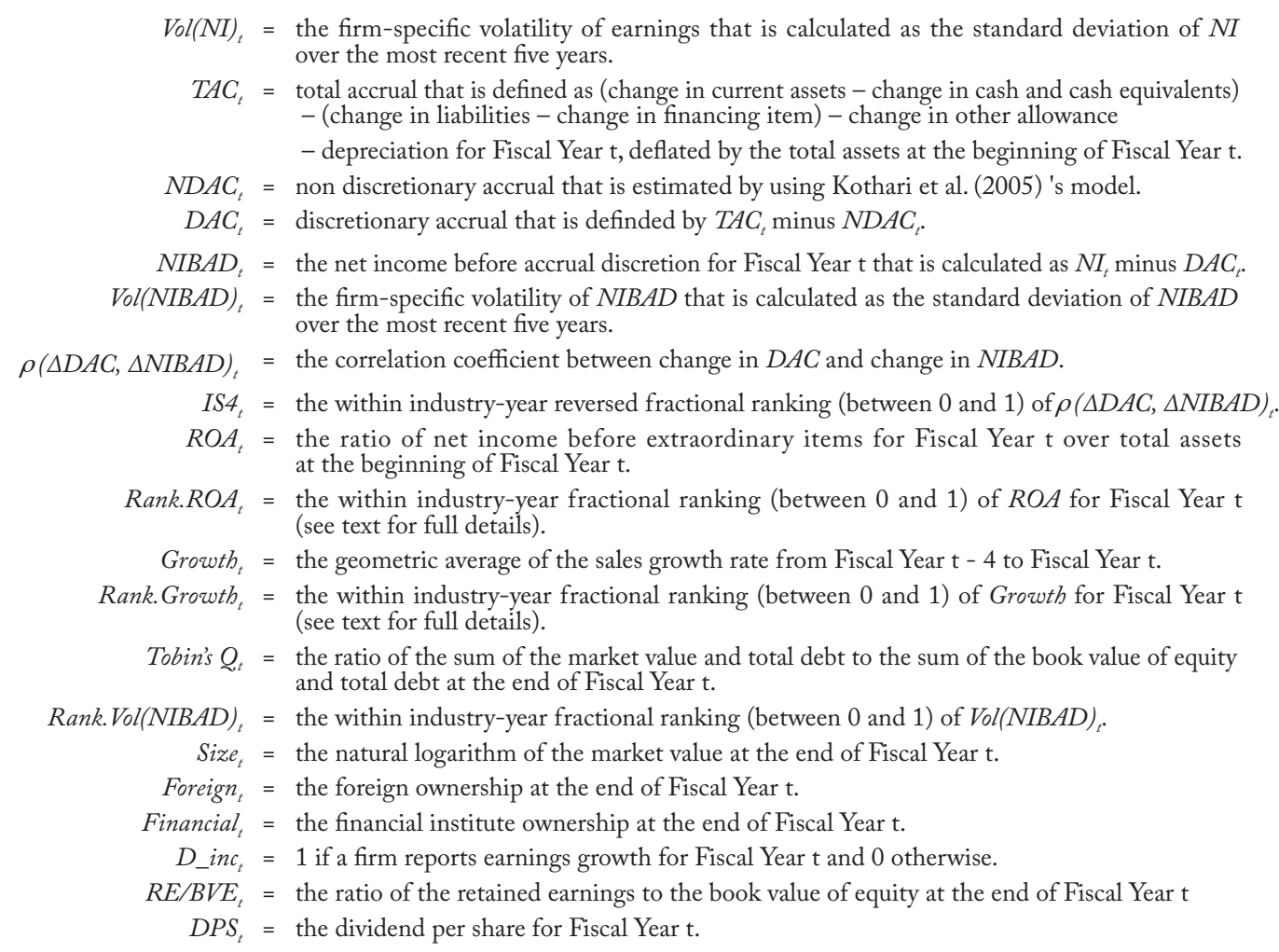

All z-statistics are corrected for heteroskedasticity, and cross-sectional and time-series correlation using a two-way cluster at the firm and year level proposed by Petersen (2009) and Cameron et al. (2011).

******, and * indicate significance at $1 \%, 5 \%$, and $10 \%$, respectively.

\section{Conclusion}

This study analyzes the information contents of income smoothing behavior, especially the role of income smoothing behavior as a signal about future performance. What do smoothed earnings tell us about the future? To answer this research question, this paper focuses on earnings persistence and dividend policy based on two prior survey papers by Graham et al. (2005) and Suda and Hanaeda (2008). These two issues are the foci of this study, based on Japanese managers' responses to questions regarding their motivation for income smoothing. In a survey study in Japan, the top two reasons given by managers as to why they prefer smoothed income were that (1) it enables stable dividends and (2) it assures customers/suppliers that the business is stable (Suda and Hanaeda 2008).

This paper provides two new pieces of evidence. First, income smoothing in the previous period relates positively to future earnings persistence. This implies that income smoothing behavior reflects high earnings persistence in the future. Second, firms that engaged in more smoothing will tend to pay stable dividends in the future, even when we control for past dividend policy, fundamental factors, and corporate governance factors. Given Lintner (1956)'s argument that the change in dividend amount is dependent 
on the change in the level of long-term and persistent earnings, it would appear that income smoothing behavior reflects long-term stability of firm performance. Therefore, income smoothing is informative with respect to a firm's future stable dividends, in line with the findings within the signaling literature.

In aggregating these pieces of evidence, it becomes clear that Japanese managers, on average, tend to smooth earnings with future earnings performance in mind. Skinner and Soltes (2011) found that dividends function as a signal of a firm's future earnings persistence. The current study's findings suggest that income smoothing in the previous five years plays a role of signaling both future dividends stability and future earnings persistence. It should be noted that income smoothing behavior itself incorporates valuable information.

This study makes several contributions to the literature and understanding of income smoothing behavior. First, we build on recent advances in the literature vis-à-vis earnings quality, especially income smoothing. Although most prior studies focus on economic consequence of income smoothing, few studies provide evidence as to whether or not income smoothing reflects future performance. The current study fills this gap.

Second, the empirical evidence supports the information view rather than a garbling view of income smoothing. This study sheds light on the bright side of smoothed earnings rather than its dark side.

In technical terms, the current study's definition of income smoothing is comprehensive, as it encompasses both accrual-based discretion and real discretion. In addition, the results are robust to alternative definitions of "income smoothing".

This study, of course, has several limitations. Most importantly, it does not cover market valuation concerning income smoothing. Francis et al. (2004) examined a link between cost of capital and income smoothing, and they find a negative association between them. In contrast, McInnis (2010) found no evidence those smooth earnings paths lead to a lower cost of equity. A survey study, on the other hand, found that 36.17 percent of Japanese top-level managers answered that having their firms be "perceived as less risky by investors" was an important factor in choosing to take a smooth earnings path. This answer was the fourth most frequently cited factor. "Reduce the return that investors demand," meanwhile, was in seventh place, with 18.57 percent of the responses (Suda and Hanaeda 2008). The economic consequences of income smoothing in the capital market would be the next issue to be explored, in future research. ${ }^{23}$

This study suggests that, with regard to firms that have succeeded in income smoothing, income smoothing behaviors in the past may provide private information about future stability of firm performance. The current study, however, provides few implications about firms that failed in income smoothing. Some prior literature examines about these firms. For instance, Myers et al. (2007) and Shuto (2010) found that firms with long strings of consecutive increases in earnings enjoyed economically significant abnormal returns while the strings were ongoing and suffered significant stock price declines when the strings were broken. These results might be one of negative economic consequences of income smoothing. It is not until understanding both effects of succeeding in income smoothing and that of failing that we can understand a complete picture of economic consequences of income smoothing. This is another topic that is to be explored in the future research.

\footnotetext{
${ }^{23}$ For example, Takasu (2012) attempts to figure out this puzzle. He uses cost of bank loans as a proxy for cost of capital. From his analysis, he finds an information asymmetry between a firm and capital providers plays a key role that determines the relation between income smoothing behavior and cost of capital.
} 


\section{REFERENCES}

ACHARYA, V. V., Y. AMinud, AND L. LiTOV. 2011. Creditor rights and corporate risk-taking. Journal of Financial Economics 102 (October): 150-166.

BARTH, M. E., W. R. LANDSMAN, AND M. H. LANG. 2008. International accounting standards and accounting quality. Journal of Accounting Research 46 (June): 467-498.

Bhattacharya, U., H. DaOUK, AND M. WelKer. 2003. The world price of earnings opacity. The Accounting Review 78 (July): $641-$ 678.

Brav, A., J. R. Graham, C. R. Harvey, And R. Michaely. 2005. Payout policy in the 21st century. Journal of Financial Economics 77 (September): 483-527.

Cameron, A. C., J. B. Gelbach, And D. L. Miller. 2011. Robust inference with multi-way clustering. Journal of Business Eซ Economic Statistics 29 (April): 238-249.

COHEN, D. A., A. DEY, AND T. Z. LYS. 2008. Real and accrual - based earnings management in the pre- and post-sarbanes-oxley periods. The Accounting Review 83 (May): 757-787.

Dechow, P. M., R. G. SloAn, And A. P. SweEney. 1995. Detecting earnings management. The Accounting Review 70 (April): $193-$ 225.

DECHOW, P. M., W. GE, AND C. SCHRAND. 2010. Understanding earnings quality: A review of the proxies, their determinants and their consequences. Journal of Accounting and Economics 50 (December): 344-401.

Denis, D. J., AND I. Osobov. 2008. Why do firms pay dividends? International evidence on the determinants of dividend policy. Journal of Financial Economics 89 (July): 62-82.

Dichev, I., AND V. W. TANG. 2009. Earnings volatility and earnings predictability. Journal of Accounting and Economics 47 (March): 160-181.

Francis, J., R. LAFond, P. M. Olsson, AND K. Schipper. 2004. Costs of equity and earnings attributes. The Accounting Review 79 (October): 967-1010.

Graham, J. R., C. R. HARVEY, AND S. RAJGOPAL. 2005. The economic implications of corporate financial reporting. Journal of Accounting and Economics 40 (December): 3-73.

GunNy, K. A. 2010. The relation between earnings management using real activities manipulation and future performance: Evidence from meeting earnings benchmarks. Contemporary Accounting Research 27 (September): 855-888.

HEALY, P. M. 1985. The effect of bonus schemes on accouting decisions. Journal of Accounting and Economics 7 (April): 85-107.

Herrmann, D., T. InOUe, AND W. B. Thomas. 2003. The sale of assets to manage earnings in Japan. Journal of Accounting Research 41 (March): 89-108.

HunT, A., S. MOYER, AND T. SHEvLin. 2000. Earnings volatility, earnings management, and equity value. Working Paper, University of Washington.

IsHIKaWA, H. 2007. Dividend Policy An Empirical Analysis. Tokyo, JAPAN: Chuokeizai-Sha (in Japanese).

JoHn, K., L. LiTOV, AND B. YEUnG. 2008. Corporate governance and risk-taking. The Journal of Finance 63 (August): $1679-1728$.

JONES, J. J. 1991. Earnings management during import relief investigations. Journal of Accounting Research 29 (Autumn): $193-228$.

Kothari, S. P., A. J. LEONE, AND C. E. WASLEY. 2005. Performance matched discretionary accrual measures. Journal of Accounting and Economics 39 (February): 163-197.

LeuZ, C., D. NANDA, AND P. D. WysOcKI. 2003. Earnings management and investor protection: An international comparison. Journal of Financial Economics 69 (September): 505-527.

LINTNER, J. 1956. Distribution of incomes of corporations among dividends, retained earnings, and taxes. The American Economic Review 46 (May): 97-113.

MCLNNIS, J. 2010. Earnings smoothness, average returns, and implied cost of equity capital. The Accounting Review 85 (January): 315-341.

Myers, J. N., L. A. Myers, AND D. J. Skinner. 2007. Earnings momentum and earnings management. Journal of Accounting, Auditing and Finance 22 (April): 249-284.

NAKANO, M. AND TAKASU, Y. 2011. Earnings persistence and earnings management. Hitotsubashi review of commerce and management 6 (May): 15-29 (in Japanese).

Petersen, M. A. 2009. Estimating standard errors in finance panel data sets: Comparing approaches. The Review of Financial Studies 22 (January): 435-480.

SERITA, T., H. HANAEDA, AND T. SASAKI. 2011. Payout policy and share splitting in Japan —Empirical study based on survey of institutional investors-. Japan Journal of Finance 31(June): 2-25 (in Japanese).

SHUTO, A. 2010. Earnings Management: Theory and Empirical Evidence from Japan. Tokyo, JAPAN: Chuokeizai-Sha (in Japanese).

SHUTO, A., AND T. IWASAKI. 2012. Stable shareholdings, the decision horizon problem, and patterns of earnings management. Working Paper, Kobe University.

SKINNER, D. J., AND E. SOLTES. 2011. What do dividends tell us about earnings quality? Review of Accounting Studies 16 (March): $1-28$. 
SudA, K., AND H. HANAEDA. 2008. Corporate financial reporting strategy: Survey evidence from Japanese firms. Securities Analysts Journal 46 (May): 51-69 (in Japanese).

TAKASU, Y. 2012. Income smoothing and the cost of bank loans-the effect of information asymmetry-. Working Paper Series, Hitotsubashi University.

Tucker, J. W., AND P. A. Zarowin. 2006. Does income smoothing improve earnings informativeness? The Accounting Review 81 (January): 251-270. 